National Water Quality Program

\title{
Using Regional Watershed Data to Assess Water-Quality Impairment in the Pacific Drainages of the United States
}

Scientific Investigations Report 2021-5087

U.S. Department of the Interior

U.S. Geological Survey 
Cover. The lower Snake River, which forms part of the border between Idaho and Oregon, has been identified by both states as an impaired waterway because of excess nutrients. (Photograph by Ken Tiffan, U.S. Geological Survey, public domain image, https://www.usgs.gov/media/images/hells-canyon-snake-river.) 


\section{Using Regional Watershed Data to Assess Water-Quality Impairment in the Pacific Drainages of the United States}

By Daniel R. Wise

National Water Quality Program

Scientific Investigations Report 2021-5087 


\section{U.S. Geological Survey, Reston, Virginia: 2021}

For more information on the USGS - the Federal source for science about the Earth, its natural and living resources, natural hazards, and the environment—visit https://www.usgs.gov or call 1-888-ASK-USGS.

For an overview of USGS information products, including maps, imagery, and publications, visit https://store.usgs.gov/.

Any use of trade, firm, or product names is for descriptive purposes only and does not imply endorsement by the U.S. Government.

Although this information product, for the most part, is in the public domain, it also may contain copyrighted materials as noted in the text. Permission to reproduce copyrighted items must be secured from the copyright owner.

Suggested citation:

Wise, D.R., 2021, Using regional watershed data to assess water-quality impairment in the Pacific Drainages of the United States: U.S. Geological Survey Scientific Investigations Report 2021-5087, 29 p., https://doi.org/10.3133/ sir20215087.

ISSN 2328-0328 (online) 


\section{Acknowledgments}

The author would like to thank the following state water-quality database managers: Matthew Correa of the California Department of Water Resources, Jason Fales of the Idaho Department of Environmental Quality, Darrin Kron and Jolene McQuillan of the Montana Department of Environmental Quality, and Mark Von Prause of the Washington Department of Ecology. 



\section{Contents}

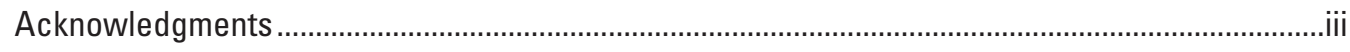

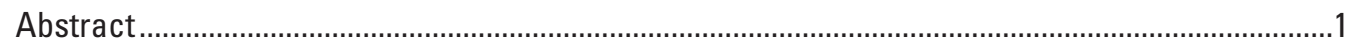

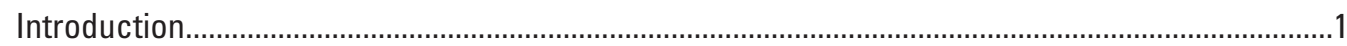

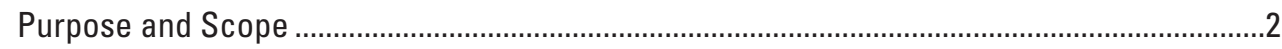

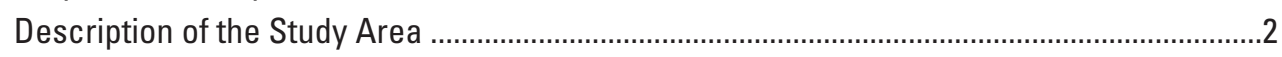

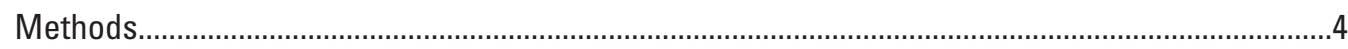

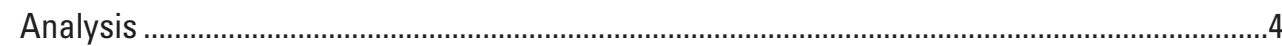

Nutrient and Water-Use Conditions..............................................................................

Linear Regression Models ...........................................................................................

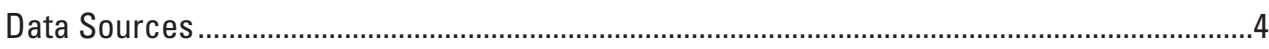

SPAtially Referenced Regression On Watershed Attributes (SPARROW) Model

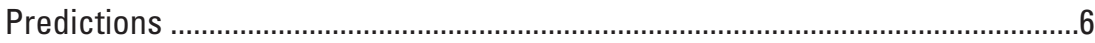

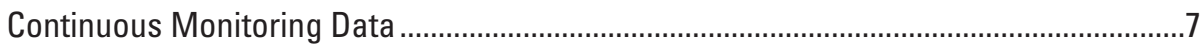

Model Calibration Data .....................................................................................................

Model Validation Data................................................................................................

Stream Temperature Data ...................................................................................... 10

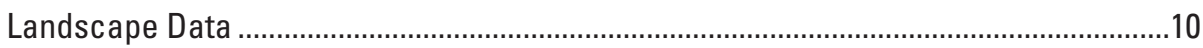

Impaired Water Bodies.................................................................................................11

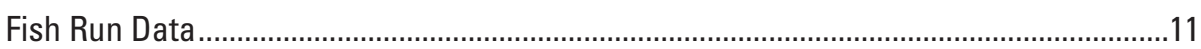

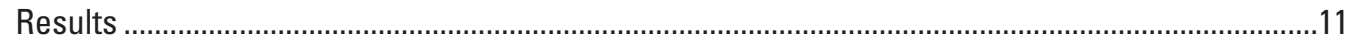

Nutrient Conditions for Impaired Water Bodies ………….....................................................11

Dissolved Oxygen and pH Regression Model Results..........................................................15

Dissolved Oxygen and pH Conditions ................................................................................20

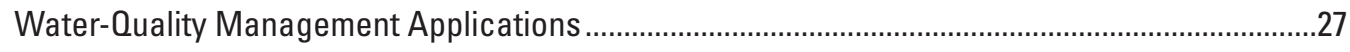

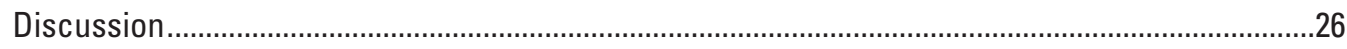

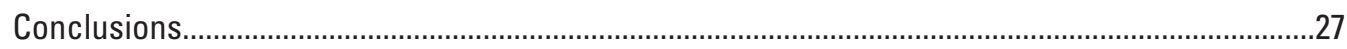

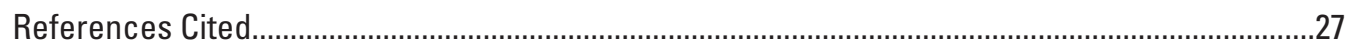




\section{Figures}

1. Map showing the Pacific drainages of the United States. .3

2. Map showing station locations and calibration data used in the dissolved oxygen linear regression model for Pacific drainages

3. Map showing station locations and calibration data used in the $\mathrm{pH}$ linear regression model for Pacific drainages.

4. Graph comparing upstream land cover for the stations supplying the calibration data used in the dissolved oxygen and $\mathrm{pH}$ linear regression models to land cover for all Pacific drainages

5. Map showing the largest contributor to total nitrogen load delivered to impaired water bodies in the Pacific drainages of the United States

6. Map showing the largest contributor to total phosphorus load delivered to impaired water bodies in the Pacific drainages of the United States

7. Diagnostic plots for the dissolved oxygen linear regression model developed for the Pacific drainages.

8. Diagnostic plots for the $\mathrm{pH}$ linear regression model developed for the Pacific drainages

9. Map showing reach-scale values for mean warm-weather minimum daily dissolved oxygen concentration predicted by the dissolved oxygen linear regression model developed for the Pacific drainages...

10. Map showing reach-scale values for mean warm-weather maximum daily $\mathrm{pH}$ predicted by the $\mathrm{pH}$ linear regression model developed for the Pacific drainages........22

\section{Tables}

1. Attributes that were evaluated as explanatory variables in dissolved oxygen and $\mathrm{pH}$ regression models developed for the Pacific drainages of the

United States

2. Summary of SPARROW nutrient modeling for impaired water bodies in the Pacific drainages of the United States

3. Model statistics for the dissolved oxygen linear regression model developed for the Pacific drainages of the United States.

4. Model statistics for the $\mathrm{pH}$ linear regression model developed for the Pacific drainages of the United States.

5. Nutrient and water-use conditions for selected impaired water bodies in the Pacific drainages of the United States 


\section{Conversion Factors}

U.S. customary units to International System of Units

\begin{tabular}{|c|c|c|}
\hline Multiply & By & To obtain \\
\hline \multicolumn{3}{|c|}{ Area } \\
\hline acre & 0.4047 & hectare (ha) \\
\hline acre & 0.004047 & square kilometer $\left(\mathrm{km}^{2}\right)$ \\
\hline \multicolumn{3}{|c|}{ Volume } \\
\hline ounce, fluid (fl. oz) & 0.02957 & liter (L) \\
\hline pint (pt) & 0.4732 & liter $(\mathrm{L})$ \\
\hline quart (qt) & 0.9464 & liter (L) \\
\hline gallon (gal) & 3.785 & liter $(\mathrm{L})$ \\
\hline \multicolumn{3}{|c|}{ Mass } \\
\hline ounce, avoirdupois (oz) & 28,349 & Milligram (mg) \\
\hline pound, avoirdupois (lb) & 0.4536 & kilogram $(\mathrm{kg})$ \\
\hline \multicolumn{3}{|c|}{ Application rate } \\
\hline pound per acre per year ([lb/acre]/yr) & 1.121 & kilogram per hectare per year $([\mathrm{kg} / \mathrm{ha}] / \mathrm{yr})$ \\
\hline
\end{tabular}

International System of Units to U.S. customary units

\begin{tabular}{lcl}
\hline \multicolumn{1}{c}{ Multiply } & By & \multicolumn{1}{c}{ To obtain } \\
\hline hectare (ha) & 2.471 & acre \\
square kilometer $\left(\mathrm{km}^{2}\right)$ & 247.1 & acre \\
square kilometer $\left(\mathrm{km}^{2}\right)$ & 0.3861 & square mile $\left(\mathrm{mi}^{2}\right)$ \\
\hline \multicolumn{3}{c}{ Volume } \\
\hline liter $(\mathrm{L})$ & 33.81402 & ounce, fluid (fl. oz) \\
liter $(\mathrm{L})$ & 2.113 & pint $(\mathrm{pt})$ \\
liter $(\mathrm{L})$ & 1.057 & quart $(\mathrm{qt})$ \\
liter $(\mathrm{L})$ & 0.2642 & gallon (gal) \\
\hline & Mass & \\
\hline milligram $(\mathrm{mg})$ & 0.00000353 & ounce, avoirdupois $(\mathrm{oz})$ \\
kilogram $(\mathrm{kg})$ & 2.205 & pound avoirdupois $(\mathrm{lb})$ \\
\hline & Application rate & \\
\hline kilogram per hectare per year $([\mathrm{kg} / \mathrm{ha}] / \mathrm{yr})$ & 0.8921 & pound per acre per year $([\mathrm{lb} / \mathrm{acre}] / \mathrm{yr})$ \\
\hline
\end{tabular}

Temperature in degrees Celsius $\left({ }^{\circ} \mathrm{C}\right)$ may be converted to degrees Fahrenheit $\left({ }^{\circ} \mathrm{F}\right)$ as follows:

$$
{ }^{\circ} \mathrm{F}=\left(1.8 \times{ }^{\circ} \mathrm{C}\right)+32 .
$$

\section{Datums}

Vertical coordinate information is referenced to the North American Vertical Datum of 1988 (NAVD 88).

Horizontal coordinate information is referenced to the North American Datum of 1983 (NAD 83). 


\section{Abbreviations}

EPA U.S. Environmental Protection Agency

NPDAT Nitrogen and Phosphorus Pollution Data Access Tool

USGS U.S. Geological Survey

WATERS Watershed Assessment, Tracking \& Environmental Results System 


\title{
Using Regional Watershed Data to Assess Water-Quality Impairment in the Pacific Drainages of the United States
}

\author{
By Daniel R. Wise
}

\section{Abstract}

Two datasets containing the first complete estimates of reach-scale nutrient, water use, dissolved oxygen, and $\mathrm{pH}$ conditions for the Pacific drainages of the United States were created to help inform water-quality management decisions in that region. The datasets were developed using easily obtainable watershed data, most of which have not been available until recently, and the techniques that were used provide a framework for integrating watershed data to assess waterquality impairment across other large hydrologic regions in the United States. These datasets were used to summarize regional nutrient and water-use conditions within impaired water bodies and to summarize regional dissolved oxygen concentrations and $\mathrm{pH}$ conditions for free-flowing stream reaches. Two examples are also presented that show how the datasets can be applied to specific water-quality management issues: (1) nutrient conditions in water bodies that have recently experienced problems with harmful algal blooms; and (2) dissolved oxygen and $\mathrm{pH}$ conditions in stream reaches likely to be populated by steelhead trout (Oncorhynchus mykiss irideus) during their summer run. The nutrient and water-use estimates could help inform actions aimed at managing water-quality conditions in impaired water bodies while the dissolved oxygen and $\mathrm{pH}$ predictions could be useful as screening tools to identify water bodies experiencing potential impairment.

\section{Introduction}

Government agencies responsible for managing watersheds for a variety of uses and benefits rely on many types of information to guide their assessments, management, and decision making. It's important that these agencies have access to readily available water-quality and watershed data that represent the time period in which they are interested, but until recently such data were often incomplete, outdated, or non-existent. With the advent of large-scale spatial datasets describing atmospheric, hydrologic, and terrestrial characteristics, detailed spatial and temporal analyses at the watershed level can now be performed to help inform management decisions. The U.S. Environmental Protection Agency's (EPA)
Watershed Assessment, Tracking \& Environmental Results System (WATERS; EPA, 2020a) and Nitrogen and Phosphorus Pollution Data Access Tool (NPDAT; EPA, 2020b), which bring together watershed data that were previously available only from several independent and unconnected databases, are examples of how national watershed data can be compiled and made available through on-line databases. While both the WATERS and NPDAT applications can help inform local water-quality assessments, they are limited to nationally available datasets. This report describes how regional watershed data were used to assess water-quality impairment related to nutrient enrichment in the Pacific drainages of the United States, which are the watersheds that ultimately drain to the Pacific Ocean.

Nutrient over-enrichment is a serious threat to inland waters throughout most of the United States (U.S. Geological Survey, 1999) and is also a problem within the Pacific drainages (California Water Resources Control Board, 2017; Idaho Department of Environmental Quality, 2017; Montana Department of Environmental Quality, 2017; Oregon Department of Environmental Quality 2017; Washington Department of Environmental Conservation, 2017; Wyoming Department of Environmental Quality, 2017). Many of the streams, ponds, lakes, and reservoirs within the Pacific drainages included on recent state 303(d) lists of impaired water bodies were placed there because they were not supporting their designated beneficial uses (for example, drinking water, recreation, aquatic life, and irrigation) due to excessive nutrient levels, nuisance algal or rooted plant growth, low dissolved oxygen concentrations, or elevated $\mathrm{pH}$. These types of impairment are often associated with increases in primary productivity related to nutrient enrichment caused by humans (known as "cultural eutrophication," but referred in this report as simply "eutrophication"), but there are other factors such as wastewater discharge, water use, water temperature, and soil chemistry that can influence nutrient impairment when it occurs.

The six states with jurisdiction over the Pacific drainages (California, Idaho, Montana, Nevada, Oregon, Washington, and Wyoming) use a variety of water-quality and watershed data to assess water bodies with regards to eutrophication. Because of the substantial resources required to obtain acceptable data with regards to quantity (both temporally and spatially) and quality; however, it is not possible for these 
water-quality agencies to do site-specific assessments of all water bodies. A general indication of the overall ecological health of the water bodies within the Pacific drainages is provided by the EPA's National Rivers and Streams Assessment (NRSA). The NRSA, which all six states participate in, is a collaborative probabilistic survey that provides a statistical representation of the condition of rivers and streams across a region and the key stressors that affect them. The states use data collected through the NRSA in their evaluations of individual water bodies as part of their assessment process but do not use those data to perform state-wide assessments of eutrophication. The states also identify the important sources of nutrients causing impairment as part of their Total Maximum Daily Load (TMDL) development process. While the contributions from point sources (for example, wastewater treatment plants and other permitted dischargers) are typically easy to estimate because of the legal requirements for facilities to perform routine monitoring and submit those results to state regulatory agencies, the contributions from diffuse (often called "non-point") sources such as agriculture, urban runoff, and natural sources are often difficult to quantify or are not readily available. One tool that allows water-quality managers to account for both point and non-point nutrient sources is the Spatially Referenced Regression On Watershed Attributes (SPARROW) model, which was developed by the U.S. Geological Survey (USGS) (Schwarz and others, 2006).

\section{Purpose and Scope}

This report describes how SPARROW predictions and other available watershed data were used to develop two new datasets that can help state regulatory agencies assess waterquality impairment within the Pacific drainages. These two datasets are available in an accompanying USGS data release (Wise, 2021). The first dataset consists of reach-scale estimates of nutrient conditions (loads, yields, concentrations, and the contribution from different sources) and water use, which water-quality managers can use to identify the contribution from different sources to the nutrient loads delivered to individual water bodies and evaluate their susceptibility to water stress. The second dataset consists of reach-scale predictions for two indicators of water-quality impairment often associated with eutrophication: (1) mean warm-weather minimum daily dissolved oxygen concentration and (2) mean warm-weather maximum daily $\mathrm{pH}$. These predictions were based on multiple linear regression models that related measured values for those indicators to mean annual SPARROW predictions and other watershed data. This approach is substantially different than conventional approaches to modeling dissolved oxygen and $\mathrm{pH}$ conditions such as the CE-QUALW2 model (Cole and Wells, 2006) and QUAL2K model (Chapra and others, 2012), which use detailed measurements or estimates of climatic and in-stream conditions to simulate diel water-quality conditions. It is not feasible, however, to use those rigorous approaches to evaluate thousands of stream reaches across an entire watershed or across a state the way the predictions described in this report can be used. The dataset representing dissolved oxygen and $\mathrm{pH}$ conditions resulted from a novel type of analysis that was only possible because of the recent availability of SPARROW predictions and other watershed data.

\section{Description of the Study Area}

The Pacific drainages cover a total area of 1,060,580 square kilometers and include the Columbia River basin, the watersheds draining to Puget Sound, the coastal drainages of Washington, Oregon, and California, the Klamath River basin, the Sacramento River basin, the San Joaquin River basin, and the watersheds surrounding San Francisco Bay (fig. 1). In 2011, scrub and grassland covered 39 percent of the modeling domain, forest covered 34 percent, agricultural areas covered 10 percent, urbanized areas covered 4.3 percent, and the remaining areas consisted of various minor land cover types (Homer and others, 2015). The climate varies widely across the modeling domain, with a humid continental climate in western Washington and Oregon, a semi-arid steppe climate in eastern Oregon and Washington and most of Idaho, a Mediterranean climate along most of the California coast and in the Central Valley, a desert climate in southern California, and an alpine climate in the Sierra Nevada in California, the Cascade Range in northern California, Washington, Oregon, and the Rocky Mountains in Idaho, Montana, and Wyoming. A detailed description of the Pacific drainages, including the extensive manipulation of the natural hydrology that occurs throughout the region, is included in Wise (2019a). 


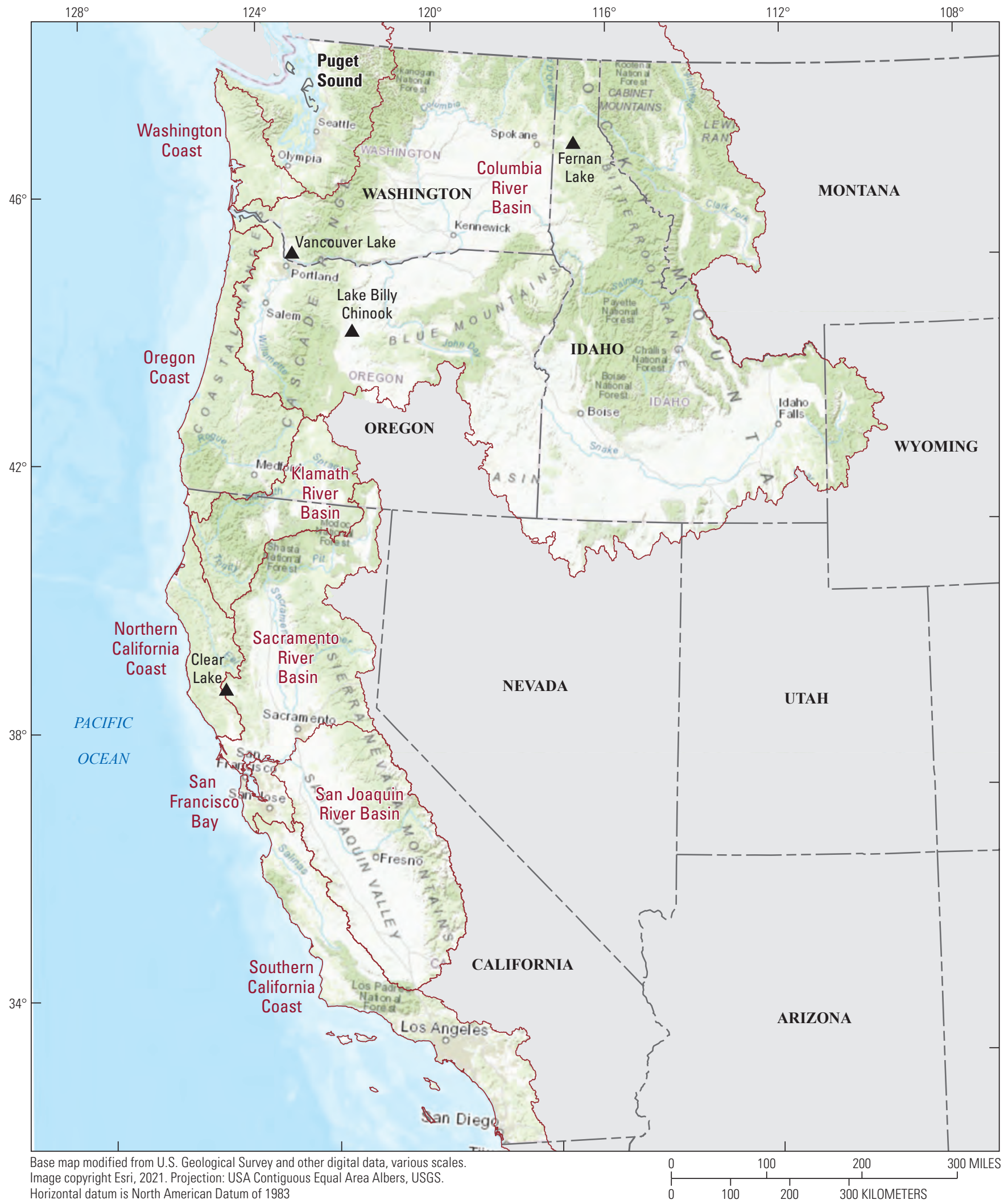

Figure 1. Pacific drainages of the United States. 


\section{Methods}

The two datasets described in this report were referenced to version 2 of the NHDPlus stream network (referred to as "the NHDPlus2" in this report; Horizon Systems, 2013). The NHDPlus2 is a comprehensive set of digital spatial data that represents streams, ponds, lakes, and reservoirs that largely correspond to the features on 1:100,000 scale USGS topographic maps. Stream reaches in the NHDPlus2 are represented by line segments that start at any point of channel initiation (headwater reaches) or a tributary junction and end at the next downstream tributary junction. The NHDPlus2 also includes the incremental catchment for almost all reaches, which is the area that drains directly to a that reach without passing through another reach. The Pacific drainages contain 324,454 NHDPlus2 incremental catchments.

\section{Analysis}

\section{Nutrient and Water-Use Conditions}

Nutrient and water-use conditions were estimated for all NHDPlus2 stream reaches. A subset of that larger dataset was selected to represent water bodies in the Pacific drainages that were not supporting their designated beneficial uses because of impairment related to eutrophication (based on the state 303 [d] lists for 2012), which was consistent with the time frame represented by the watershed data used in this analysis. Nutrient conditions, as estimated by the USGS SPARROW models developed for the Pacific drainages for 2012 (Wise, 2019a), consisted of the mean annual total nitrogen and total phosphorus loads, yields, and flow-weighted concentrations and the contributions from individual anthropogenic and natural sources to the mean annual loads. Water-use conditions were represented by two indicators. One was a general water use index for each reach that equaled the current streamflow divided by the streamflow that would occur without any hydrologic manipulation, such as upstream water diversions and the return of water to streams through municipal wastewater discharge and runoff from irrigated land. The second indicator was a groundwater-use index for each reach that equaled the total upstream withdrawal of groundwater divided by the current streamflow in the reach. These estimates were used to provide both a regional summary of nutrient and wateruse conditions for impaired water bodies and to show the conditions in four individual impaired water bodies that have recently experienced problems with harmful algal blooms, which are a growing concern across the Pacific drainages and the United States.

\section{Linear Regression Models}

Linear regression models were developed to relate mean warm-weather minimum daily dissolved oxygen concentrations and mean warm-weather maximum daily $\mathrm{pH}$ in 40 and 45 free-flowing stream reaches, respectively, to watershed attributes that were expected to have some influence on those parameters. The explanatory attributes retained in the models represented statistically significant variables ( $\mathrm{p}$-value less than 0.05 ) that provided the best model fit based on the adjusted coefficient of determination (adjusted $\mathrm{R}^{2}$ ). Table 1 describes the stream and landscape attributes that were evaluated as explanatory variables in the dissolved oxygen and $\mathrm{pH}$ linear regression models. These explanatory variables represented one of the four general types of expected control on primary productivity: water chemistry, light availability, water temperature, and hydrology. The linear regression models were used to predict mean warm-weather minimum daily dissolved oxygen concentrations and mean warm-weather maximum daily $\mathrm{pH}$ for free-flowing NHDPlus2 stream reaches in the Pacific drainages. No predictions were made, however, for reaches where the value for at least one of the explanatory variables was either missing or outside the range of values used in the model calibrations. This meant that dissolved oxygen and $\mathrm{pH}$ predictions were made for about 83 percent of the 313,032 NHDPlus2 reaches representing free-flowing streams. An example application of those predictions is also presented that shows how they can be used to assess potential impairment in stream reaches likely to be populated by steelhead trout (Oncorhynchus mykiss irideus) during their summer run in the Pacific drainages.

\section{Data Sources}

The five types of data used to develop the datasets described in this report were:

(1) recent SPARROW model predictions of streamflow, total nitrogen, total phosphorus, and sediment for the Pacific drainages;

(2) minimum daily dissolved oxygen concentrations and maximum daily $\mathrm{pH}$ measured at USGS continuous monitoring stations;

(3) results from the U.S. Forest Service NorWest stream temperature modeling project;

(4) values for selected landscape parameters; and

(5) data describing the spatial extent of steelhead trout summer runs. 


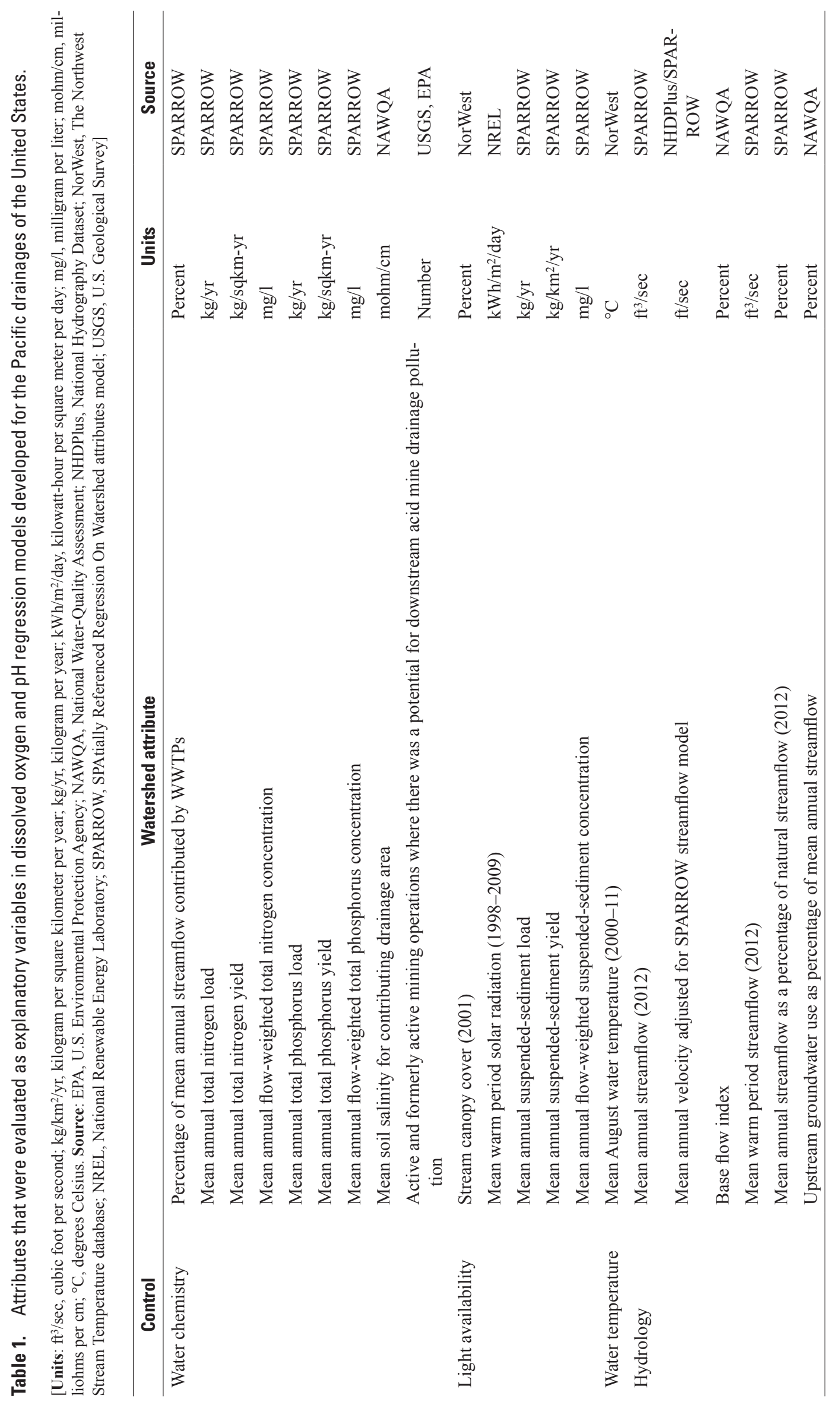




\section{SPAtially Referenced Regression On Watershed Attributes (SPARROW) Model Predictions}

The USGS developed SPARROW models for the Pacific drainages for streamflow and three water-quality constituentstotal nitrogen, total phosphorus, and suspended sediment that represented 2012 conditions (Wise, 2019a). The analysis described in this report used either the original predictions from those models or the predictions resulting from minor modifications to the input data for those models. These modifications were made to either correct some of the input data used in original models or to represent conditions that were not within the scope of the original modeling. All predictions represent mean annual conditions for water years 2000-14 that were detrended to water year 2012, which was necessary to account for differences in record length, hydrologic conditions, and sample size among the calibration stations used in the models. This means that the predictions reflect landscape conditions for water year 2012 but mean annual hydrologic conditions for water years 2000 through 2014. Saad and others (2019) and Wise (2019a) contain a detailed description of how SPARROW models were developed for the Pacific drainages, including the limitations, uncertainties, and potential biases associated with the model SPARROW model input data and model predictions.

Two corrections were made to the input data used in the original SPARROW nutrient models to obtain more accurate estimates of reach-scale nutrient conditions. The predictions from the original nutrient models included the contribution from all land classified as "developed" under the 2011 National Land Cover Database (Homer and others, 2015), and this meant that the in-stream nutrient loads predicted by those models included the contribution from paved and unpaved roads. While this contribution was relatively small in urban areas, it was often incorrectly predicted to be the largest nutrient source in many undeveloped areas within the Pacific drainages (Wise, 2019a). To correct this problem, the input data were modified so that the contribution from developed land was limited to those areas located within delineated towns and cities. The predictions from the original total phosphorus model also included the contribution from cattle grazing manure applied to land that was determined to be suitable for grazing, which included areas located within national forests. While grazing manure phosphorus from these forested areas made up only 11 percent of the total contributed by grazing cattle, it was often predicted to be the largest phosphorus source in many areas within the Pacific drainages. Based on discussions with water-quality managers, however, these results do not reflect actual conditions. To correct this problem, the input data for the total phosphorus model were modified so that the contribution form grazing manure was limited to those areas that did not represent forest land.

Because of the way the mean annual flow-weighted nutrient concentrations predicted by the SPARROW models were calculated, there were a very small number of reaches with extremely high values for this parameter. The mean annual flow-weighted concentration for a reach was equal to the SPARROW-estimated mean annual load divided by the SPARROW-estimated mean annual streamflow, and the estimated mean annual streamflow was close to zero in some reaches. This led to unrealistically high estimates of mean annual flow-weighted concentration (sometimes greater than $1,000 \mathrm{mg} / \mathrm{l})$. To overcome this problem, the estimated mean annual flow-weighted concentrations for total nitrogen and total phosphorus were capped at more realistic (but still very high) values. These values were 70 and $12 \mathrm{mg} / 1$, respectively, which represent the highest concentrations of total nitrogen and total phosphorus typically measured in raw sewage (Tchobanoglous and others, 2003).

The predictions from the original streamflow model accounted for consumptive water use for public water supply and agriculture as well as the return of that water to streams through municipal wastewater discharge and runoff from irrigated land, respectively. These diversions include 642 municipal water supply intakes and 248 irrigation withdrawals. The model also accounted for 72 water transfers that occur either within river basins or between river basins. The original streamflow model was used to run a scenario that did not include any of these types of water manipulations to provide an estimate of natural streamflow conditions. These predictions were then used to calculate the general water-use index described earlier that was equal to the current streamflow expressed as a percentage of the natural streamflow.

Because of the spatially explicit nature of the watershed data that were used as input to the 2012 SPARROW models, the contribution to the estimated load in a reach from sources that were not directly accounted for in the models can still be estimated for that reach. The contribution from indirectly modeled sources was estimated for two total phosphorus sources (fertilizer applied to farmland and wastewater discharge) and four total nitrogen sources (fertilizer applied to farmland, wastewater discharge, atmospheric deposition, and runoff from developed land) that were directly accounted for in the models.

(1) The contribution to total nitrogen and total phosphorus load from all fertilizer applied to farmland was disaggregated into the contributions from commercial fertilizer and livestock manure, which were the two forms of fertilizer that made up that source (Wise, 2019b). The contribution from livestock manure used as fertilizer was further disaggregated into its two individual components, which were manure from cattle housed in concentrated animal feeding operations (such as dairies and feedlots) and manure from non-cattle livestock such as poultry, horses, and sheep.

(2) The contribution to total nitrogen and total phosphorus load from wastewater discharge was disaggregated into the contribution from aquaculture facilities such as hatcheries and fish farms and the contribution from other types of discharge, which was primarily from sewage treatment plants (Skinner and Wise, 2019). 
(3) The contribution to total nitrogen load associated with atmospheric nitrogen deposition was disaggregated into the separate contributions from oxidized nitrogen (from combustion sources) and reduced nitrogen (from agricultural sources-primarily livestock) (Wieczorek and others, 2019).

(4) The contribution to total nitrogen load associated with runoff from developed land primarily represented two sources-fertilizer use and leaching from onsite wastewater treatment (mostly septic tanks), but this source could not be disaggregated into its separate components in the total nitrogen model because of the way it was parameterized. A general indication of the contribution from onsite wastewater treatment to the in-stream total nitrogen loads was estimated, however, by expressing the upstream population served by onsite wastewater treatment (Wise, 2019c) as a percentage of the total upstream population.

\section{Continuous Monitoring Data}

The results from continuous water-quality monitoring provided the data for the dependent variables in the dissolved oxygen and $\mathrm{pH}$ regression models. The USGS has a wellestablished network of water-quality stations in the Pacific drainages where high-quality continuous data have been collected over many years and have undergone a thorough quality-control review of the methods and procedures used to collect and process the data. There is also a limited amount of state and local agency continuous water-quality data available for the Pacific drainages. Based on a review of the non-USGS data and discussions with the state water-quality database managers, however, it was determined that using just USGS data, collected with consistent quality-control and review processes, minimized potential sources of bias in datasets and afford the most consistent quantitative results across all Pacific drainages. Therefore, only the USGS results were used in the development of the dissolved oxygen and $\mathrm{pH}$ linear regression models to ensure that those models were based on the highest quality data available.

\section{Model Calibration Data}

The USGS National Water Information System (U.S. Geological Survey, 2019a, https://dx.doi.org/10.5066/ F7P55KJN) was queried to obtain the daily minimum dissolved oxygen concentrations and daily maximum $\mathrm{pH}$ values measured at USGS continuous monitoring stations between water years 2000 and 2014. To account for nonstationarity in the data, the original daily values were detrended by centering them on the midpoint of each station record. The mean warm period (July 1-August 31 ) values for the detrended daily values for each station were calculated, and each station was referenced to an NHDPlus2 reach. Dissolved oxygen and $\mathrm{pH}$ data were retained for calibration of the linear models if they represented the warm weather seasons for at least 4 different years. Only the most downstream station was retained when two or more stations were located within the same HUC12 watershed and on the same primary flow path. This approach was used to minimize potential calibration bias from station clustering. Additionally, stations that were not located on free-flowing streams (that is, they were located within a pond, lake, or reservoir), stations with data that were not representative of the stream cross section (for example, studies targeting suspected low dissolved oxygen locations), and stations that were heavily influenced by upstream conditions that could not be accounted for in the regression explanatory data (for example, high dissolved oxygen concentrations downstream of a dam or low dissolved oxygen concentrations downstream of a severely eutrophic water body) were not retained.

The final dataset of mean warm period daily minimum dissolved oxygen concentrations included 40 stations (minimum: $2.10 \mathrm{mg} / 1$, maximum: $11.74 \mathrm{mg} / 1$, mean: $7.18 \mathrm{mg} / \mathrm{l}$, number of values for a single station ranging from 130 to 917) (fig. 2), and the final dataset of mean warm period daily maximum $\mathrm{pH}$ included 45 stations (minimum: 6.85, maximum: 9.08, mean: 7.90, number of values for a single station ranging from 150 to 917) (fig. 3). Although the total number of stations used in the linear regression models was small given the large area being modeled, the stations did provide good spatial representation of the region-and the land cover for the areas draining to those stations was generally representative of the land cover for all the Pacific drainages (fig. 4). Most of the stations, however, were located within or close to areas dominated by urban development or agriculture, and only a few stations were in areas consisting mostly of forest, scrub, shrub, or grass land (figs. 2, 3). This pattern was not surprising because water-quality studies tend to focus on impaired water bodies, but it might have introduced some bias into the regressions that were used to develop the dissolved oxygen and $\mathrm{pH}$ models. 


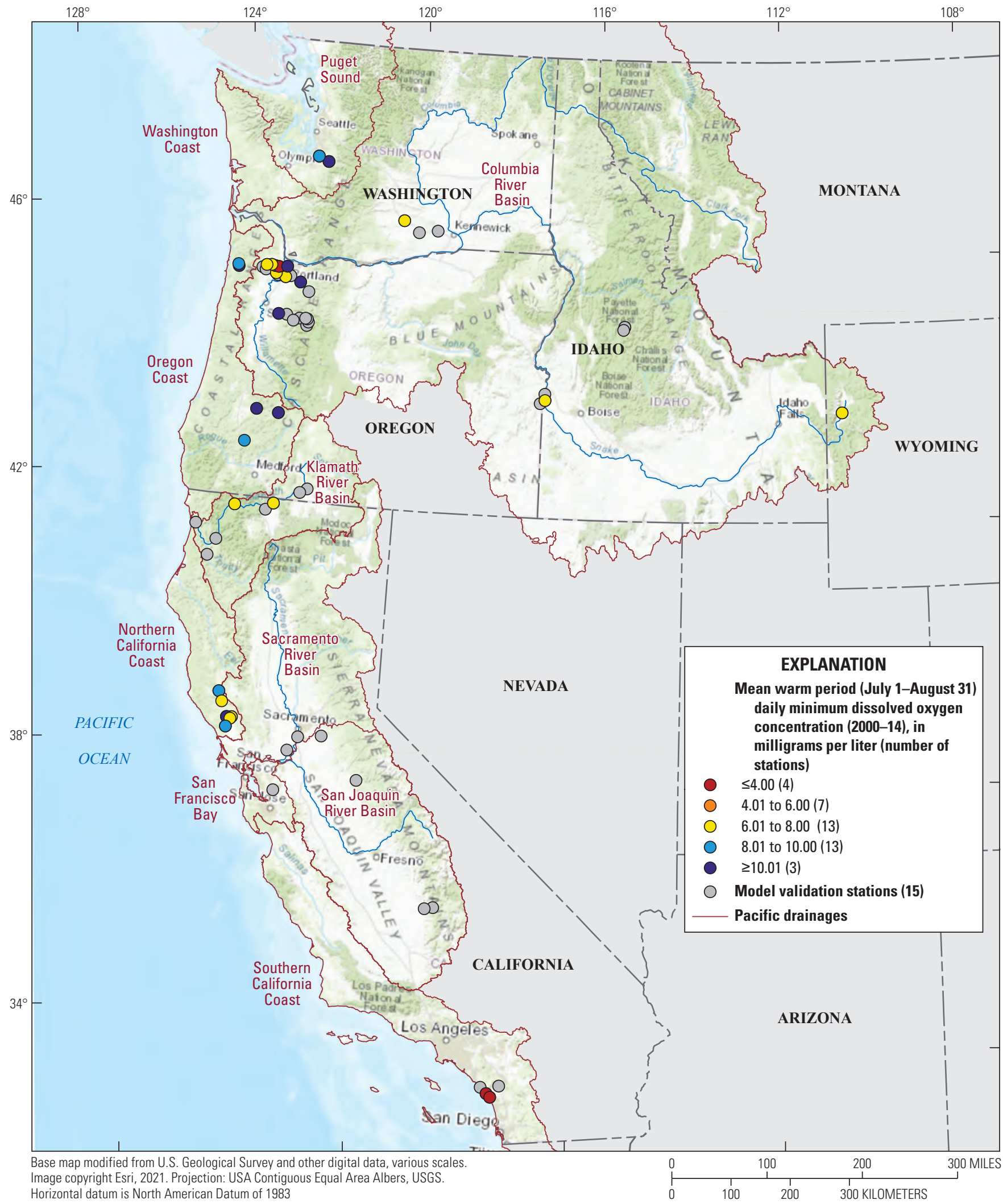

Figure 2. Station locations and calibration data used in the dissolved oxygen linear regression model for Pacific drainages. 


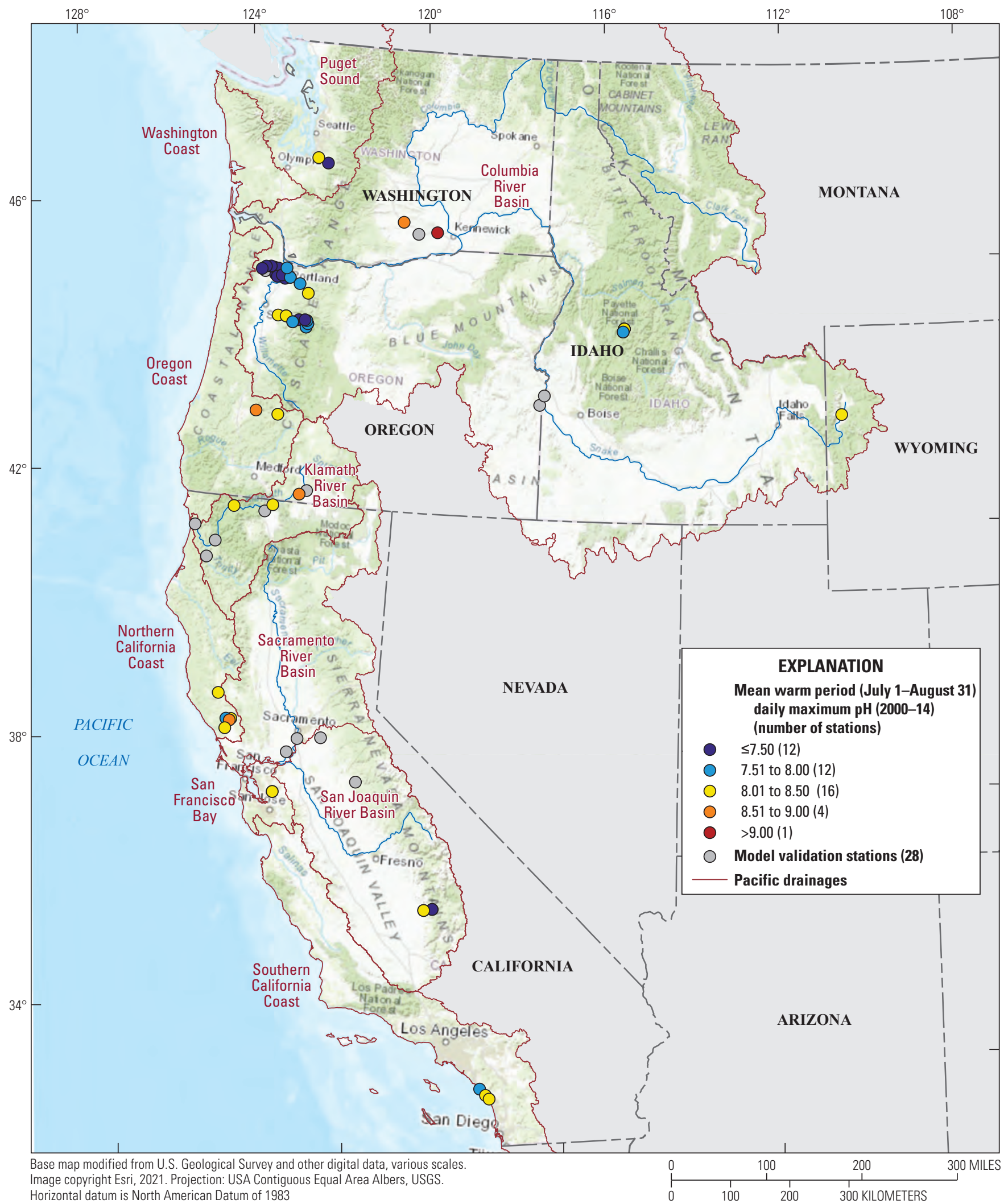

Figure 3. Station locations and calibration data used in the pH linear regression model for Pacific drainages. 

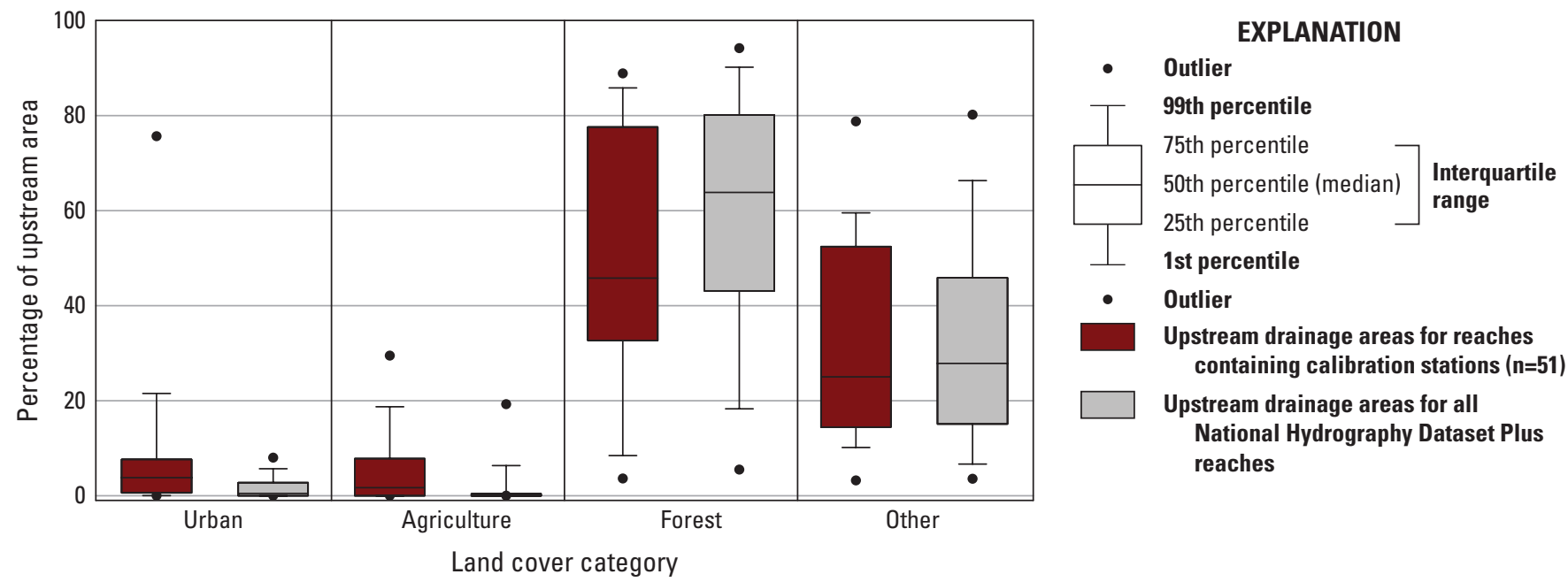

Figure 4. Comparison of upstream land cover for the stations supplying the calibration data used in the dissolved oxygen and $\mathrm{pH}$ linear regression models to land cover for all Pacific drainages.

\section{Model Validation Data}

The limited amount of data that were used to validate the dissolved oxygen and $\mathrm{pH}$ liner models came exclusively from the USGS (U.S. Geological Survey, 2019a, https://dx.doi.org/ $10.5066 /$ F7P55KJN). Some of the USGS stations had warm weather daily minimum dissolved oxygen concentration and daily maximum $\mathrm{pH}$ data that met all criteria for inclusion in the model calibrations except that the data represented fewer than 4 different years. These data provided a way to validate the dissolved oxygen regression model at 15 stations and the $\mathrm{pH}$ regression model at 28 stations. The available state data, however, were not adequate to validate the models. While there were stations where states collected continuous waterquality data, data from those stations were sometimes not accessible or were of unknown quality, the period of record was too short or contained substantial gaps, or the data represented impoundments or estuaries where the model predictions do not apply. Figures 2 and 3 show the locations of the USGS stations where model validation was performed.

\section{Stream Temperature Data}

The Northwest Stream Temperature (NorWeST) database is a repository for stream temperature data in the western U.S. It hosts more than 220,000,000 temperature recordings from more than 22,700 locations (U.S. Forest Service, 2019). Isaac and others (2017) fit a spatial-stream-network (SSN) model to a subset of the values in the NorWest database to estimate mean August water temperatures (2000-11) for each reach in the NHDPlus2 network located within the NorWest project boundary (which includes all the Pacific drainages). The NorWest database also includes estimates of stream canopy cover for each reach in the NHDPlus2 network. While mean August water temperature estimates existed for each of the reaches containing a model calibration station, there were 181 NHDPlus2 reaches that did not have a value. For those cases a value was estimated using a simple linear regression that related all available mean August water temperature values to the mean maximum annual air temperature (1971-2000) corresponding to their incremental NHDPlus2 catchment (Wieczorek and others, 2019).

\section{Landscape Data}

The landscape data evaluated in this study included two attributes that were averaged for each incremental NHDPlus2 catchment-mean summertime total solar radiation for 1998-2009 (National Renewable Energy Laboratory, 2019) and base-flow index (Wieczorek and others, 2019) and three attributes that were generalized for the total area draining to each NHDPlus2 reach-the mean soil salinity and the total withdrawal of groundwater in 2012 (Wieczorek and others, 2019), and the total number of active mining operations (U.S. Geological Survey, 2019b) and formerly active mining operations (Center for International Earth Science Information Network, 2019) where there was a potential for downstream acid mine drainage pollution (specifically, elevated $\mathrm{pH}$ levels). The formerly active operations only included those designated as "Superfund" sites under the Comprehensive Environmental Response, Compensation, and Liability Act (CERCLA) of 1980. A groundwater use index was also calculated for each reach that equaled the total upstream withdrawal of groundwater (Wieczorek and others, 2019) divided by the 2012 streamflow predicted by the SPARROW model for the reach. 


\section{Impaired Water Bodies}

A regional geo-spatial dataset of impaired water bodies for 2012 was created from the data available from each of the states with jurisdiction over the Pacific drainages or, in the case of Montana, from the EPA (California Water Resources Control Board, 2017; Idaho Department of Environmental Quality, 2017; 2017; Oregon Department of Environmental Quality, 2017; Washington Department of Environmental Conservation, 2017; Wyoming Department of Environmental Quality, 2017; U.S. Environmental Protection Agency, 2019). These datasets were downloaded and filtered to select water bodies impaired by impacts related to eutrophication and belonging to TMDL Categories 4 (water body is impaired or threatened, but a TMDL has been implemented or is not needed) or 5 (water body is impaired and a TMDL is required). The approaches for defining a water body vary between states and even within states, meaning an impaired water body can be an individual impoundment, an individual stream reach, a small group of stream reaches, or even all stream reaches within a watershed (for example, a HUC8 watershed). Because each water body needed to be referenced to a unique NHDPlus2 reach for this analysis, the most downstream NHDPlus2 reach corresponding to each listed water body was selected to represent that water body. The small number of water bodies that were extensive enough to cover more than one HUC8 watershed were divided into separate water bodies. Listed water bodies that were not represented in the NHDPlus2 (typically smaller streams, isolated ponds, and agricultural returns) were not included in the regional dataset of impaired water bodies. The resulting geospatial dataset included 1,809 water bodies within the Pacific drainages that were referenced to an NHDPlus2 reach.

\section{Fish Run Data}

Stream reaches likely to be populated by steelhead trout during their summer run in the Pacific drainages were obtained from the California Department of Fish and Wildlife (2020) and the StreamNet database maintained by the Pacific States Marine Fisheries Commission (2020). The original geo-spatial data obtained from these organizations were referenced to the NHDPlus2, and the combination of the two datasets included 43,403 reaches.

\section{Results}

\section{Nutrient Conditions for Impaired Water Bodies}

The results from this study were used to describe nutrient and water-use conditions for the 1,809 water bodies within the Pacific drainages identified by their states as nutrient-impaired. Table 2 summarizes the SPARROW nutrient modeling for those impaired water bodies, and figures 5 and 6 show the largest contributors to the total nitrogen and total phosphorus load delivered to those water bodies. The directly modeled sources in table 2 are nutrient sources that were represented in the regression equations used in the SPARROW total nitrogen and total phosphorus models and, therefore, were directly accounted for in those models. But as explained earlier, the contribution to the estimated load in a reach from sources that were not directly accounted for in the models can still be estimated-and these contributions are represented by the indirectly modeled sources in table 2 .

The SPARROW predictions showed that, on average, diffuse landscape sources, rather than point-source wastewater discharges, are the largest contributors to the total nitrogen load delivered to impaired water bodies in the Pacific drainages (table 2). While the largest mean contributions to total nitrogen load are from atmospheric deposition ( 34.0 percent) and fertilizer/manure applied to farmland (30.9 percent), there are areas where other sources dominate (fig. 5). Red alder trees are often the largest source in western Washington and Oregon, developed land is generally the largest source in the urbanized watersheds around Seattle and Portland, and springs are the largest source for many reaches of the Snake River.

The SPARROW predictions showed that diffuse landscape sources are also the largest contributors to the total phosphorus load delivered to impaired water bodies (table 2). The largest mean contributions to total phosphorus load are from natural phosphorus originating along stream channels and from weathering of upslope geology (49.4 percent) and agricultural sources (the combination of fertilizer/manure applied to farmland, and grazing cattle manure; totaling 35.9 percent) (table 2). There are also clear spatial patterns in the delivery of total phosphorus to impaired water bodies (fig. 6). Grazing cattle manure is the largest contributor to most of the water bodies in western Washington and Oregon, while natural phosphorus is the largest contributor to most of the water bodies in eastern Washington and Oregon. Fertilizer/ manure applied to farmland is generally the largest source in areas of Washington and Oregon under cultivation, whereas point-source wastewater discharge is the largest source for many reaches of the Snake River. In California, natural phosphorus and grazing cattle manure are generally the largest contributors to impaired water bodies located outside of urban areas and areas under cultivation. The largest source in urban areas within California is generally point-source wastewater discharge and the largest source in cultivated areas is generally fertilizer/livestock manure applied to farmland. 


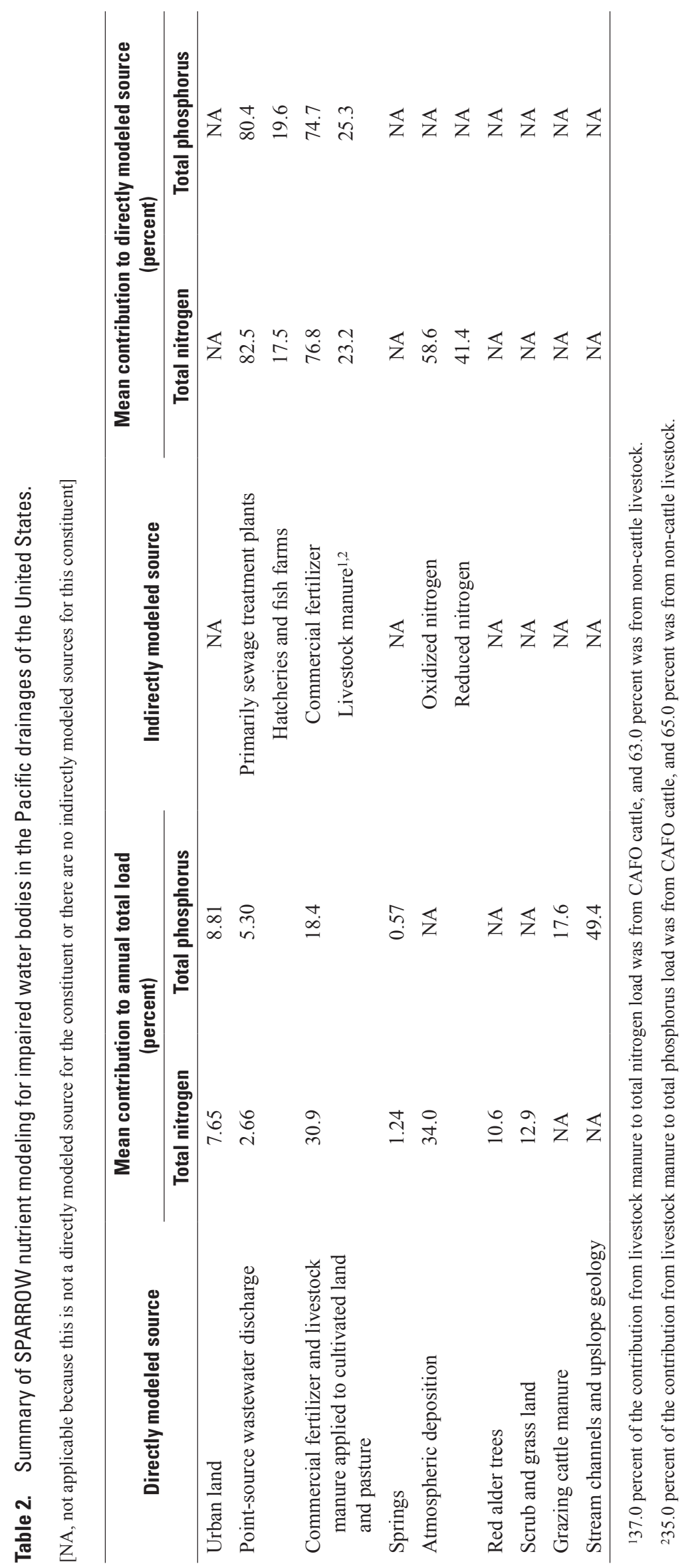




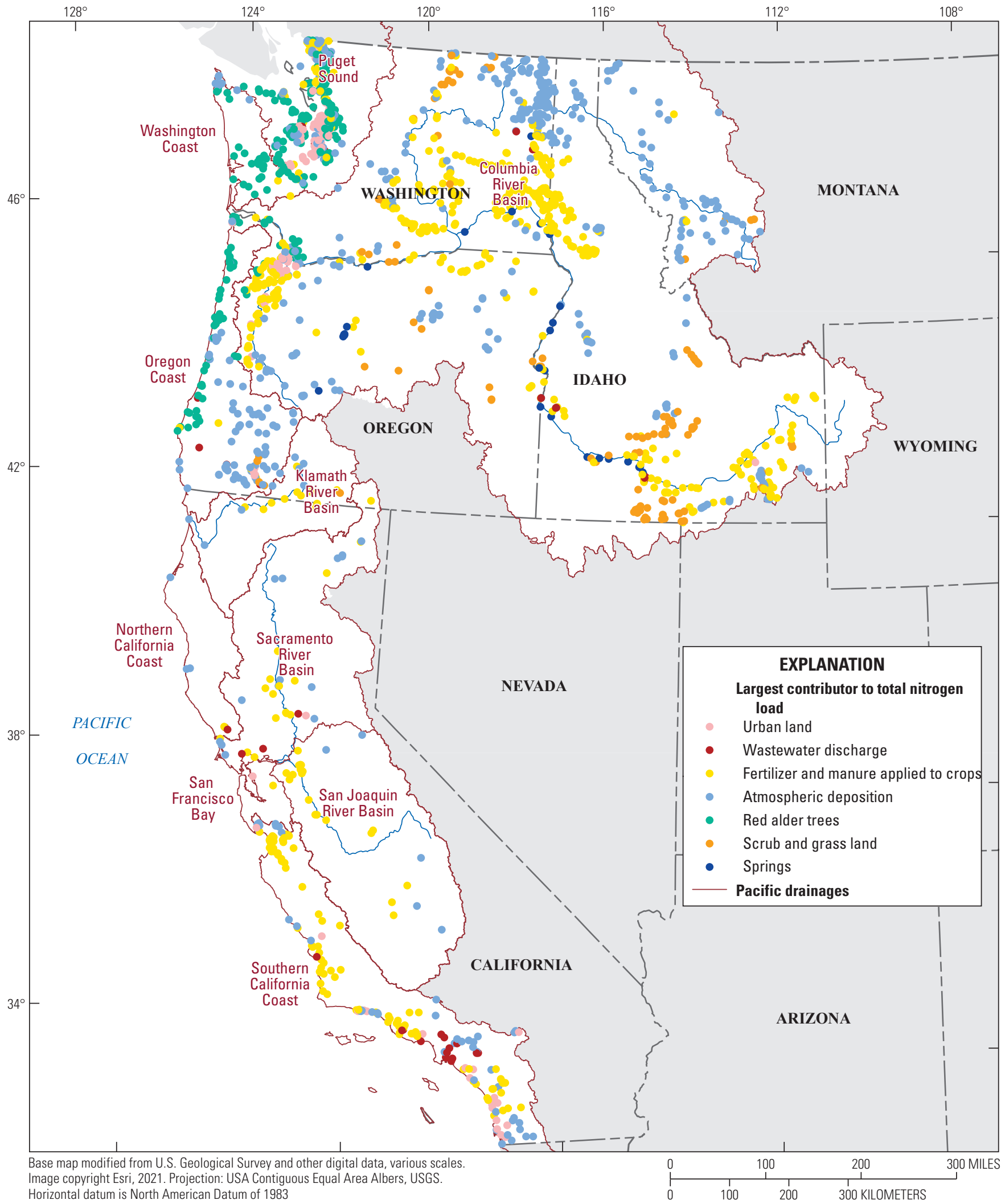

Figure 5. Map showing the largest contributor to total nitrogen load delivered to impaired water bodies in the Pacific drainages of the United States. 


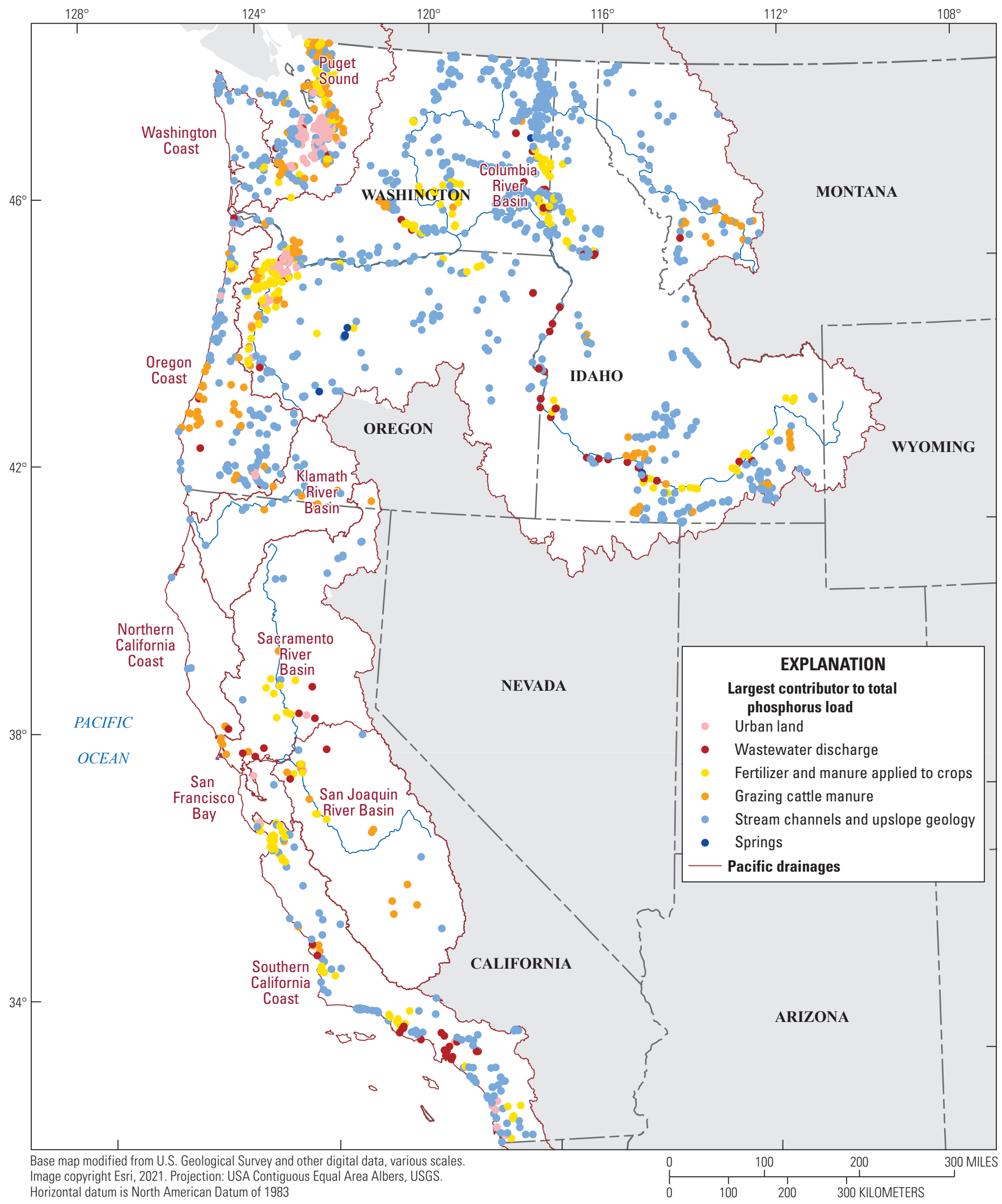

Figure 6. Largest contributor to total phosphorus load delivered to impaired water bodies in the Pacific drainages of the United States. 
In addition to the contributions from directly modeled nutrient sources shown in table 2, the contributions from indirectly modeled sources could also be useful to water-quality managers. For example, on average, most of the point-source wastewater discharge comes from sewage treatment plants, commercial fertilizer makes up most of the fertilizer/manure applied to farmland, and of most of the manure applied to farmland comes from non-cattle livestock. And for total nitrogen, table 2 provides information that can be used to estimate the total impact from agricultural activities. Grazing cattle manure was not a significant source in the total nitrogen model for the Pacific drainages, suggesting that most nitrogen from that source is lost to volatilization, denitrification, or mineralization before being delivered to streams. Given that fertilizer/ manure applied to farmland contributes on average about 31 percent to total nitrogen load, that a substantial portion of the nitrogen from grazing livestock manure is likely volatilized, and that about 41 percent of the contribution from atmospheric deposition consists of reduced nitrogen (primarily from the volatilization of nitrogen in livestock manure), agricultural activities are likely on average the largest contributor (either directly or indirectly) to the total nitrogen load delivered to many of the impaired water bodies.

\section{Dissolved Oxygen and pH Regression Model Results}

Two watershed properties, mean August water temperature and mean annual flow-weighted total nitrogen concentration, were significant predictors of mean warm-season minimum daily dissolved oxygen concentration, and both had a negative coefficient (table 3 ). These results indicate that the combined effect of lower oxygen solubility and increased plant productivity in response to warmer water with a larger supply of nutrients leads to lower dissolved oxygen concentrations. The SPARROW-estimated total phosphorus concentration was also a significant predictor (with a negative coefficient), but only when total nitrogen concentration was not included, and this reflected the strong correlation between the two parameters. Total nitrogen concentration was retained, however, because its coefficient was more significant and provided a better model fit than the coefficient for total phosphorus.

Four watershed properties were significant predictors of mean warm-season maximum daily $\mathrm{pH}$ (table 4). Negative coefficients were estimated for mean annual streamflow as a percentage of natural streamflow, mean annual total nitrogen yield from nitrogen fertilizer/manure used as fertilizer, and mean annual suspended-sediment concentration; and a positive coefficient was estimated for the mean soil salinity of the contributing drainage area. These results indicate that reaches with streamflow close to or greater than the amount expected under natural conditions (the latter situation is possible for reaches located downstream of irrigation returns and wastewater discharge) tend to be less susceptible to ecological imbalance (for example, excessive plant growth) than reaches where natural streamflow is reduced because of upstream diversions. The negative coefficient for the yield from nitrogen fertilizer/ manure could be related to the high salt content in agricultural runoff, which tends to buffer $\mathrm{pH}$ swings in streams. Suspended sediment concentration was expected to have a negative coefficient because higher concentrations are positively related to turbidity, which attenuates primary productivity (leading to lower maximum $\mathrm{pH}$ ). In contrast, soil salinity was expected to have a positive coefficient because streams draining areas containing saline soils usually have naturally elevated $\mathrm{pH}$ due to the high alkalinity of those soils.

Standard diagnostic techniques were used to evaluate the dissolved oxygen and $\mathrm{pH}$ linear regression models (figs. 7, 8). There was a strong relation between the measured values for mean warm-season minimum dissolved oxygen concentration and the predicted values (fig. 7a; adjusted $\mathrm{R}^{2}$ of 0.690 ) and between the measured values for mean warm-season maximum $\mathrm{pH}$ and the predicted values (fig. 8a; adjusted $\mathrm{R}^{2}$ of $0.701)$. The residuals for both the dissolved oxygen and the $\mathrm{pH}$ models were normally distributed (figs. 7b, 7d, 8b, 8d). Figures $7 \mathrm{~d}$ and $8 \mathrm{~d}$ include the normal distribution expected for the residuals (blue line) and a kernel plot (red line), which is a smooth curve that represents the actual distribution without assuming normality. There was also no systematic pattern observed in the relation between the residuals and the predicted values for either model (fig. 7c, 8c), which would indicate bias in the model predictions. Also, the errors associated with both model validations were greater than the errors associated with the calibrations. The root mean squared error (RMSE) for the dissolved oxygen model validation was 1.84 $\mathrm{mg} / \mathrm{l}$ compared to $1.24 \mathrm{mg} / \mathrm{l}$ for the calibration, and the RMSE for the $\mathrm{pH}$ model validation was $0.43 \mathrm{pH}$ units compared to $0.29 \mathrm{pH}$ units for the calibration. 


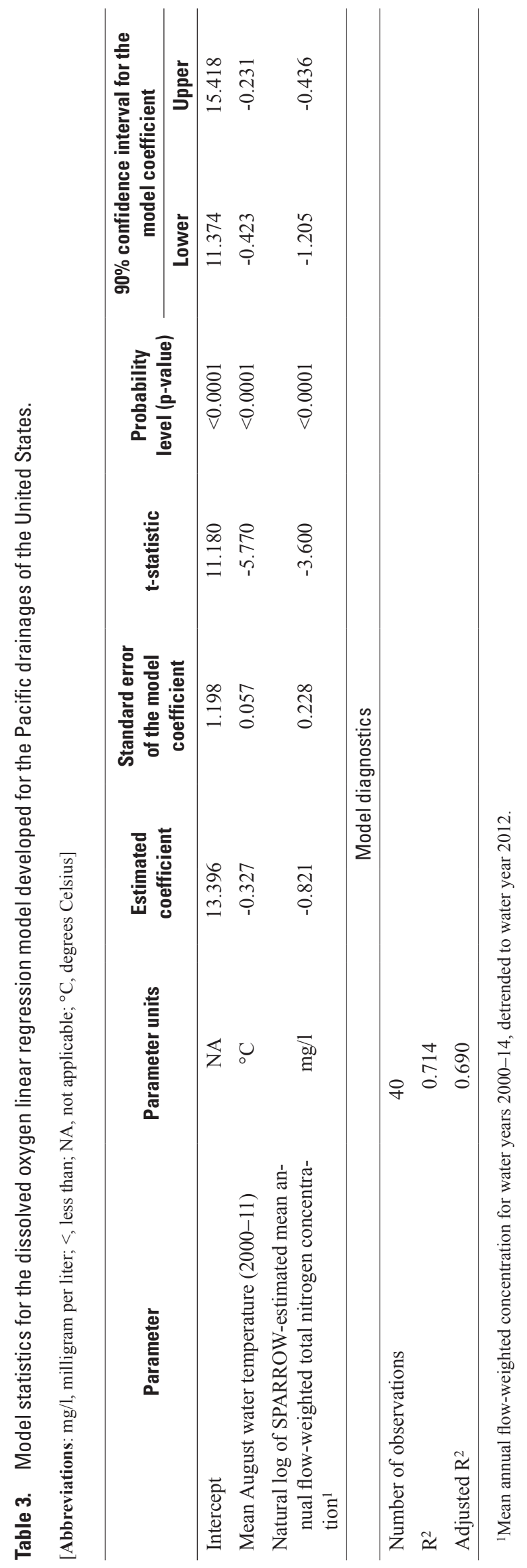


Results 17

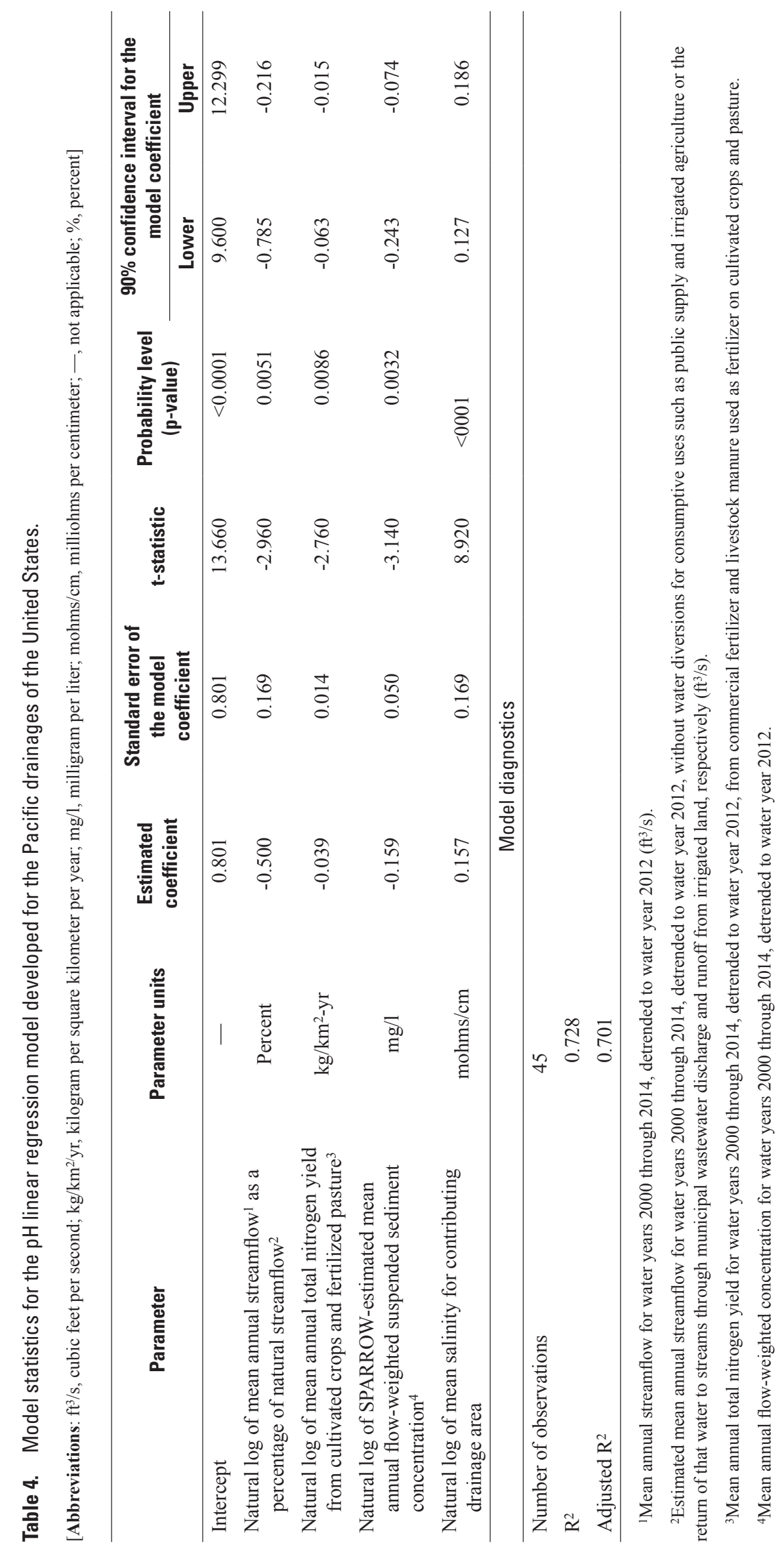



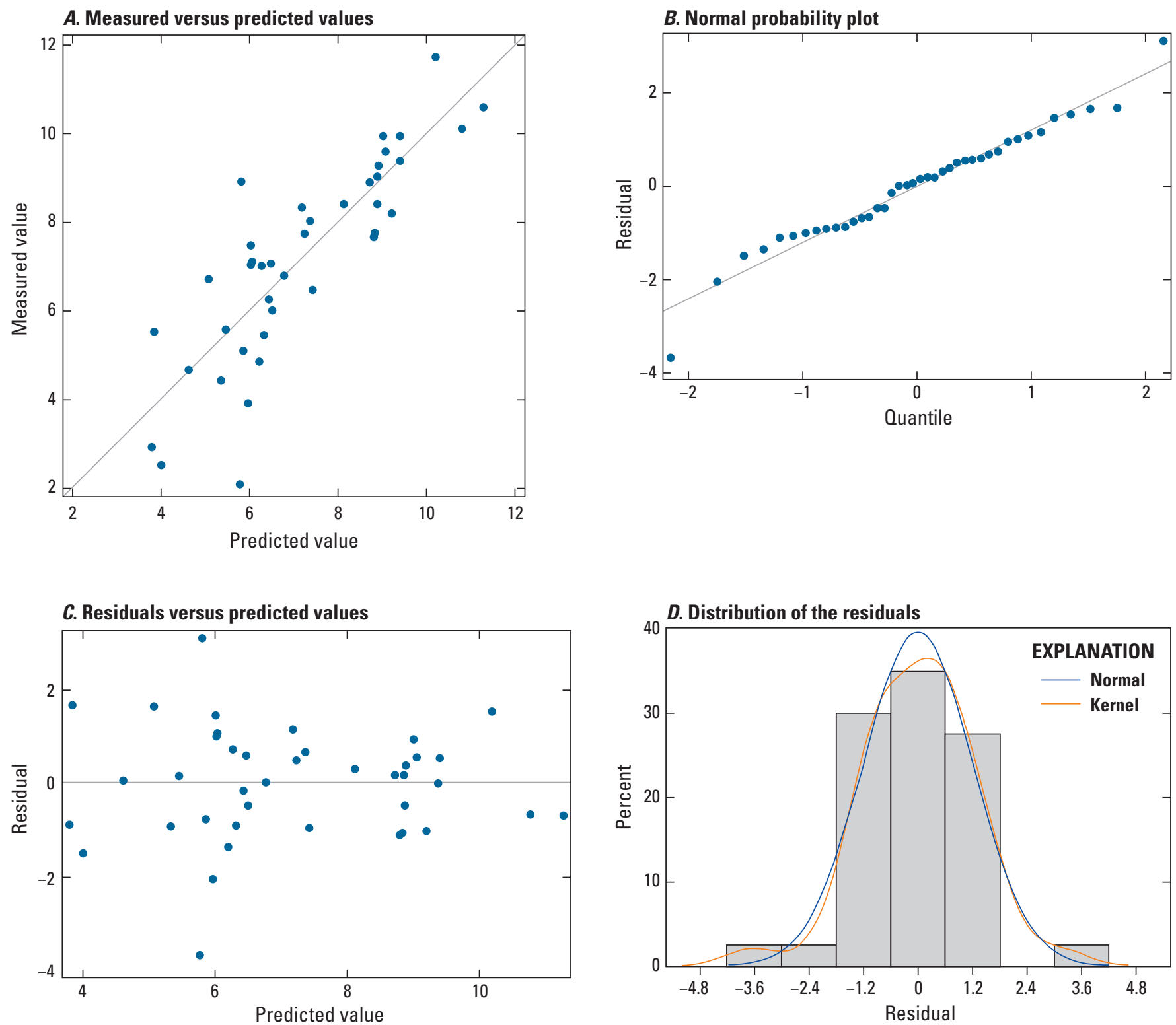

Figure 7. Dissolved oxygen linear regression model developed for the Pacific drainages. 

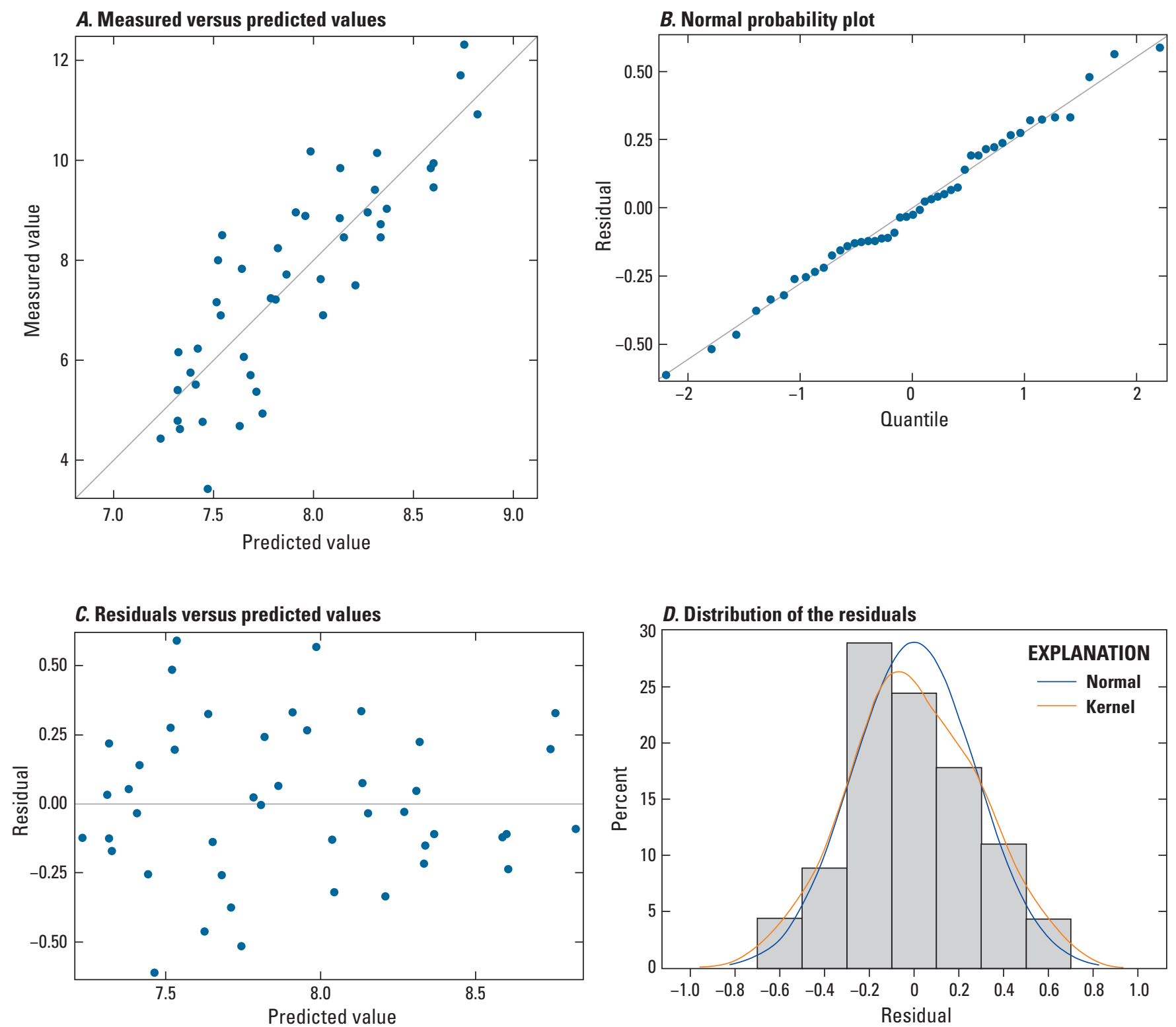

Figure 8. pH linear regression model developed for the Pacific drainages. 


\section{Dissolved Oxygen and pH Conditions}

The dissolved oxygen and $\mathrm{pH}$ linear regression models were used to predict the mean warm-weather minimum daily dissolved oxygen concentration and maximum daily pH for 2000-14 (and the corresponding 90 percent confidence intervals) for all NHDPlus2 reaches other than those representing ponds, lakes, reservoirs, and shorelines. These predictions are shown on figures 9 and 10 and summarized in the legends for those figures. The dissolved oxygen model predicted extremely low (less than $2 \mathrm{mg} / \mathrm{l}$ ) and even negative values for 6,172 of the 257,813 reaches, and these predicted values were replaced with a value of $2 \mathrm{mg} / \mathrm{l}$ (with no corresponding confidence interval), which represented a reasonable lower limit for mean warm-weather minimum daily dissolved oxygen concentration based on the measured values used in the regression. Almost all the 6,172 reaches extremely low or negative predictions were associated with very high stream temperatures (for example, about half of these reaches had a mean August stream temperature that was greater than the 95th percentile of $23.8^{\circ} \mathrm{C}$ for all the reaches in the prediction dataset). None of the 40 measured values used in the regression were below $2 \mathrm{mg} / \mathrm{l}$, however, even though many of those values were associated with reaches with mean August stream temperatures that were above $23.8^{\circ} \mathrm{C}$. In contrast, no limits were set on the upper end of the range in the predicted mean warm-weather minimum daily dissolved oxygen concentrations. While the dissolved oxygen model predicted values greater than the greatest calibration value of $11.74 \mathrm{mg} / 1$ for 61 reaches (with a maximum of $12.64 \mathrm{mg} / \mathrm{l}$ ), these were almost always predicted for high-elevation mountain streams with minimum human impact where high dissolved oxygen concentrations are observed even during warm periods. Additionally, no limits were set on the range in the predicted mean warmweather maximum daily $\mathrm{pH}(6.89-9.33)$ because the values were within the expected range for this parameter (99.9 percent of the values were also within the range of the measured values used in the regression). 
Results

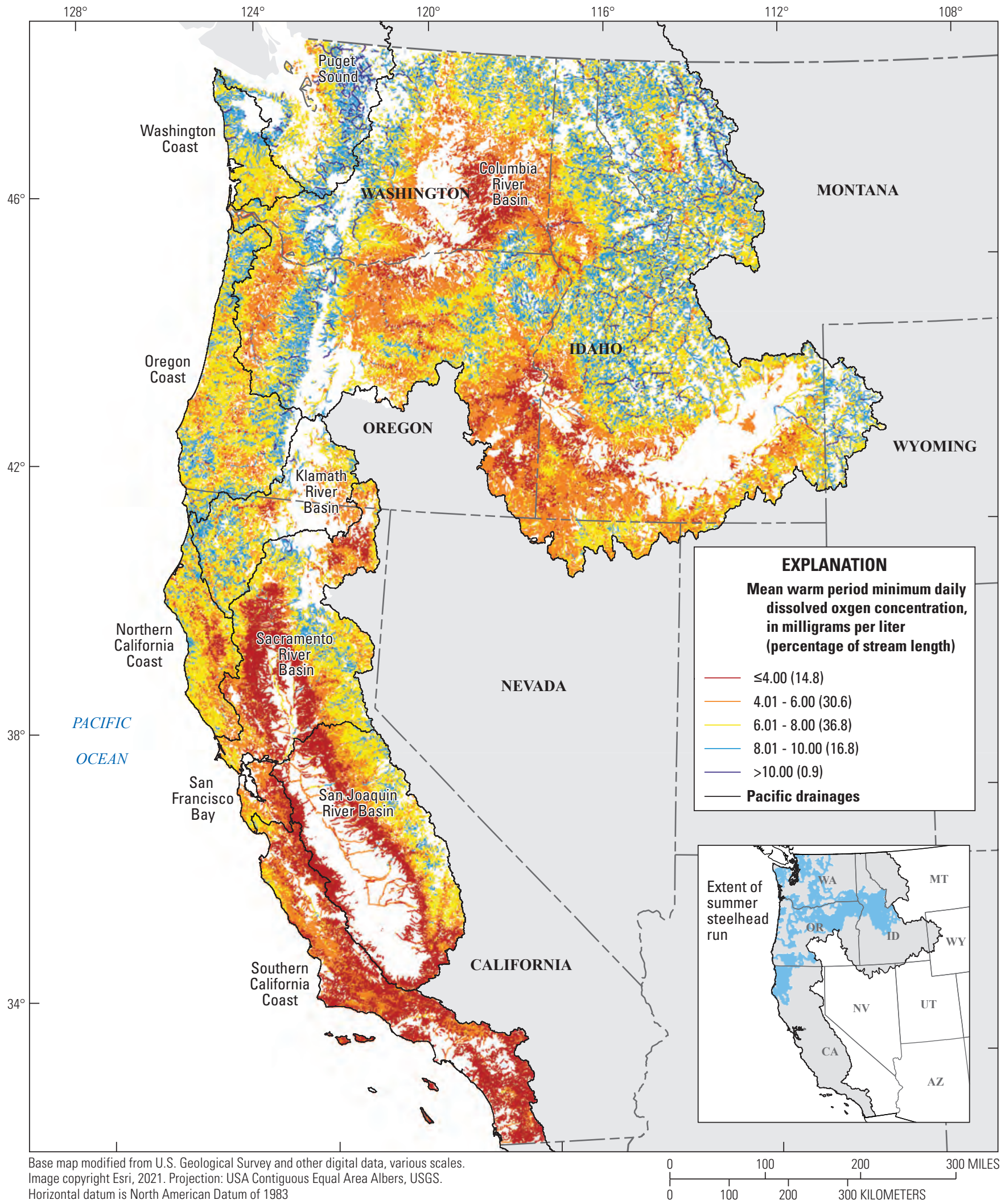

Figure 9. Reach-scale values for mean warm-weather minimum daily dissolved oxygen concentration predicted by the dissolved oxygen linear regression model developed for the Pacific drainages. 


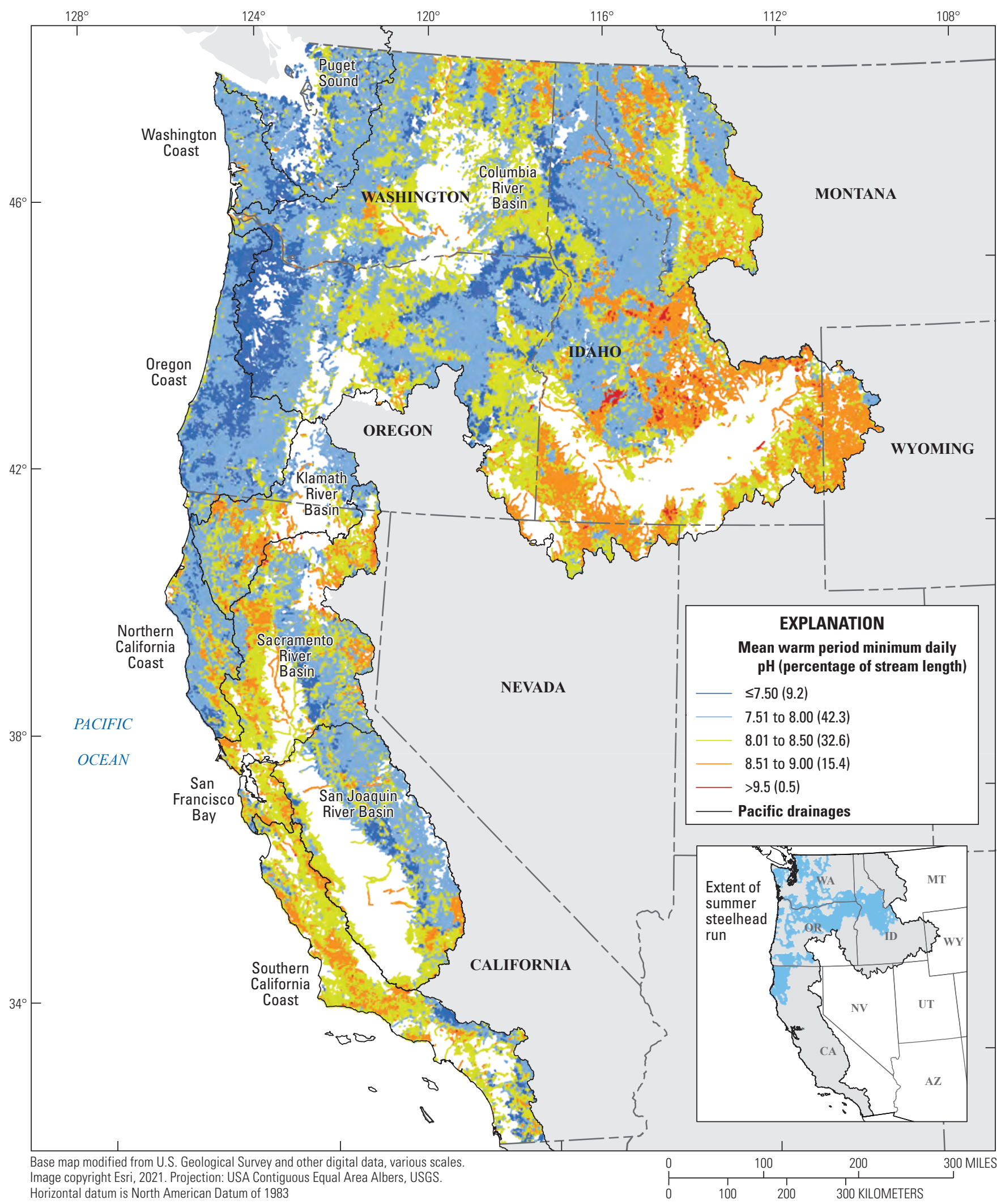

Figure 10. Reach-scale values for mean warm-weather maximum daily $\mathrm{pH}$ predicted by the $\mathrm{pH}$ linear regression model developed for the Pacific drainages. 


\section{Water-Quality Management Applications}

The two datasets described in this report were developed to help inform water-quality management decisions in the Pacific drainages of the United States, and this might be accomplished in two ways. First, water-quality managers could use the reach-scale estimates of nutrient and water-use conditions to assess water bodies with suspected or documented impairment. The data release accompanying this study (Wise, 2021) contains those results for all the NHDPlus2 reaches but also includes a field indicating the reaches that represent 1 of the 1,809 impaired water bodies shown in figures 5 and 6 (along with the state-designated identifier for each impaired water body). Second, water-quality managers could use the reach-scale predictions of dissolved oxygen and $\mathrm{pH}$ conditions to help identify impaired water bodies that have not yet been assessed.

The nutrient and water-use conditions presented in table 2 are expressed as mean values to provide a regional summary of nutrient and water-use conditions, but a unique profile can be created for any water body that is referenced to an NHDPus2 reach. The four water bodies identified on figure 1 (Clear Lake in California, Fernan Lake in Idaho, Lake Billy Chinook in Oregon, and Vancouver Lake in Washington) have three things in common that make them instructive examples. They were on their state's 2012 303(d) list due to effects related to eutrophication, they are in watersheds representing different types of landscapes, and they have recently experienced problems with harmful algal blooms, which often form in warm, impounded water bodies with abundant nutrients. Information about nutrient and water-use conditions, therefore, could be helpful to water-quality managers responsible for mitigating the impacts within these four water bodies and other water bodies experiencing similar types of impairment.

As was generally true across the Pacific drainages, diffuse landscape sources rather than point-source wastewater discharges are the largest contributors to the nutrient load delivered to these four water bodies (table 5). The largest contribution to total nitrogen delivered to Clear and Fernan Lakes is from the combination of atmospheric deposition and runoff from scrub and grass land (totaling 74.2 and 86.5 percent for each lake, respectively). The largest contribution to total phosphorus delivered to Clear Lake is from the combination of cattle grazing, manure, and natural sources (stream channels, and upslope geology) (totaling 63.5 percent), and the largest contribution to total phosphorus delivered to Fernan Lake is from natural sources (77.9 percent). Spring discharge is the largest contributor to both total nitrogen and total phosphorus delivered to Lake Billy Chinook (89.3 and 48.3 percent for each contaminant, respectively) and runoff from developed land is the largest contributor to both total nitrogen and total phosphorus delivered to Vancouver Lake (66.7 and 73.8 percent for each contaminant, respectively). What these results suggest is that, if nutrient supply is an important control on the severity of harmful algal blooms in these water bodies, mitigating those impacts through reductions in watershed nutrient inputs might prove difficult.

The predictions of dissolved oxygen and $\mathrm{pH}$ conditions described in this report might be useful by themselves or in combination with other data like the results from the NRSA to screen large numbers of water bodies for impairment. Waterquality managers could identify individual stream reaches where the predicted warm-weather values exceed applicable dissolved oxygen or $\mathrm{pH}$ criteria or they could evaluate entire watersheds based on the percentage of stream length that is predicted to exceed those criteria. This might be useful information, for example, when assessing the potential impairment of stream reaches where sensitive fish species are likely to be found-such as for steelhead trout during their summer run in the Pacific drainages, which occurs between March and November. Steelhead trout, a salmonid species found in freshwater tributaries flowing to the Pacific Ocean, are the anadromous form of the rainbow trout (meaning that they migrate from the ocean into fresh water to spawn). Coldwater aquatic life water-quality standards apply to reaches where these fish are expected to inhabit, generally meaning a dissolved oxygen standard of not less than $8.0 \mathrm{mg} / \mathrm{l}$ and a pH standard of not greater than 8.5. Stream reaches where steelhead trout are expected to be found during their summer run in the Pacific drainages are shown on the inset maps in figures 9 and 10. For those reaches where predictions were made, the linear regression models predicted that 59 percent of the stream length had a mean warm-weather minimum daily dissolved oxygen concentration less than $8.0 \mathrm{mg} / \mathrm{l}$ and 11 percent of the stream length had a mean warm-weather maximum daily $\mathrm{pH}$ greater than 8.5. 


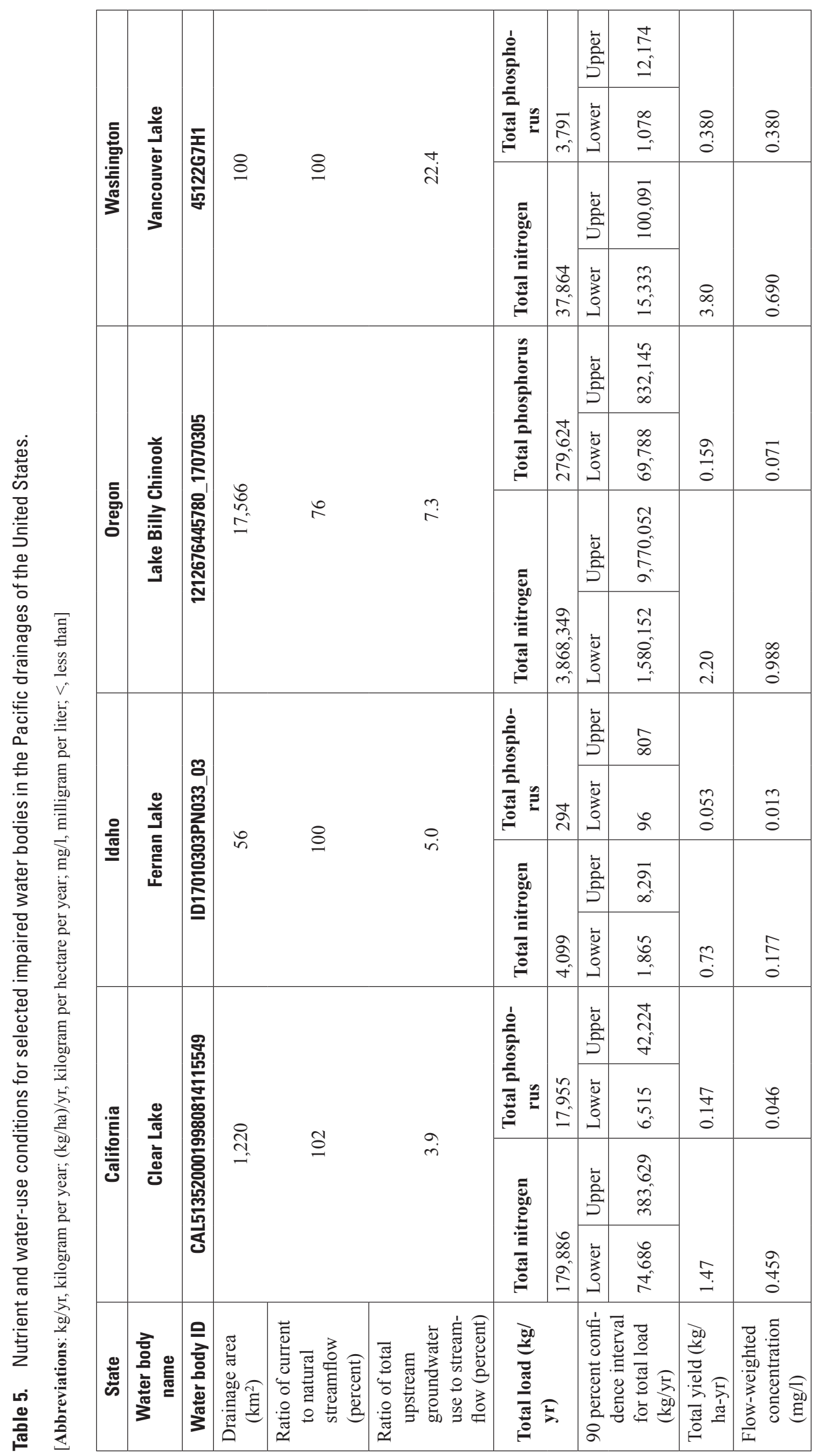




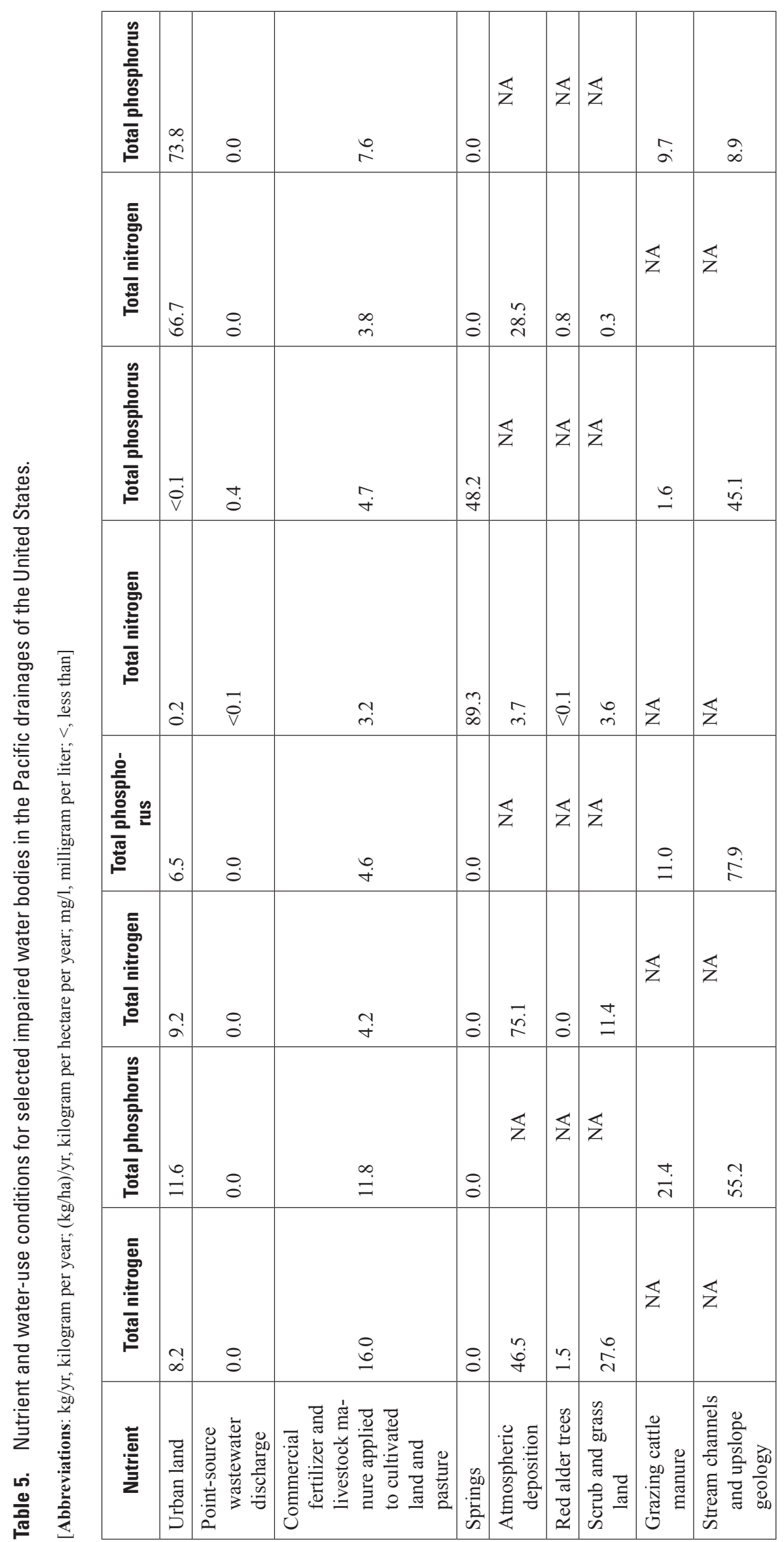




\section{Discussion}

The approaches described in the report can also be used to create similar datasets for other regions of the United States. SPARROW streamflow, nutrient, and suspended-sediment models representing 2012 conditions are currently available for the four other major hydrologic regions within the conterminous U.S.: the Southwest (Wise and others, 2019), the Midwest (Robertson and Saad, 2019), the Southeast (Hoos and Roland, 2019), and the Northeast (Ator, 2019). The input data and predictions from those regional SPARROW models provide the same type of detailed, reach-scale nutrient and water-use conditions that were estimated for the Pacific region. The dissolved oxygen and $\mathrm{pH}$ regression models developed for the Pacific drainages can likely be reproduced in the other hydrologic regions as well. Between 2000 and 2014 the USGS continuously monitored 873 stream locations across the conterminous U.S. where dissolved oxygen was measured and 745 stream locations where $\mathrm{pH}$ was measured. Only 40 values for mean warm-weather minimum daily dissolved oxygen concentration and 45 values for mean warm-weather maximum daily $\mathrm{pH}$ were needed to show a strong relation between those parameters and watershed attributes in the Pacific drainages. Therefore, there might be enough water-quality data available to build similar models for the other regions to estimate reach-scale dissolved oxygen and $\mathrm{pH}$ conditions and identify the watershed attributes that control those conditions.

The datasets described in this report and similar datasets that might be created for other hydrologic regions should be used with an understanding that, as is true with all models, there is uncertainty associated with their predictions. Therefore, water-quality managers using those predictions to assess water bodies would benefit from recognizing this uncertainty. The SPARROW estimates of reach-scale nutrient and water-use conditions include the 90 percent confidence intervals for the predicted mean annual total nitrogen and total phosphorus loads (as shown in table 5), and this information provides a useful quantitative measure of the model uncertainty. The confidence intervals for the mean annual loads, however, only represent the uncertainty associated with the model calibrations. There is also some uncertainty that was not estimated as part of the development of the Pacific region SPARROW models because this uncertainty is difficult to quantify systematically.

Some of the error in the model predictions could result from applying the regional calibration results to small watersheds, such as the one draining to Fernan Lake (table 5). The results from a mass balance on the nutrients delivered to Fernan Lake between 2014 and 2015, which relied on high intensity streamflow and water-quality monitoring (LaCroix, 2015), suggest that down-scaling the models might lead to inaccurate predictions in some watersheds. The SPARROWestimated total phosphorus yield for the Fernan Lake watershed was about 23 percent of the measured mean annual yield. The discrepancy between the predicted and measured total phosphorous yields for this watershed might be related to the way that the contribution from diffuse nutrient sources (which dominate the Fernan Lake watershed) are estimated for SPARROW modeling. Diffuse nutrient sources, such as natural phosphorus and agriculture, are estimated by interpolating data representing large areas (for example, surficial geologic units for natural phosphorus) to smaller areas. Therefore, it would not be unexpected if the relative spatial error associated with this approach was often greater for smaller watersheds compared to larger watersheds. But while that pattern would be expected for some watersheds, it would not necessarily be expected for all. Watersheds where the nutrient loads come primarily from point-source wastewater discharge, regardless of size, should have less uncertainty in the model inputs than similarly sized watersheds dominated by diffuse sources. The reason the uncertainty is less is because estimates of wastewater nutrient discharge are facility-specific and, as a result, have relatively low error.

Some of the error in the model predictions could also result from hydrologic and anthropogenic features that are unique to a watershed, such as the one draining to Vancouver Lake (table 5). The results from a mass balance on the nutrients delivered to Vancouver Lake between 2010 and 2012, which also relied on high intensity streamflow and water-quality monitoring (Sheibley and others, 2014), suggest that the presence of unusual hydrologic and anthropogenic features might lead to inaccurate predictions in some watersheds. Vancouver Lake has three inlets, but only one acts as a true surface water tributary to the lake. One of the inlets is an artificial channel that connects the lake to the Columbia River, and this channel only allows water to flow into the lake from the river when the river stage is high enough. The other inlet is a natural connection to the Columbia River that currently has bidirectional flow that changes almost every day. The SPARROW-estimated total phosphorus load delivered to Vancouver Lake from its one true surface water tributary (Burnt Bridge Creek) was about 74 percent of the measured mean annual load for that tributary, but it was only about 55 percent of the total measured net mean annual load delivered to Vancouver Lake (where net load was the total amount delivered to the lake minus the total amount that was discharged from the lake to the Columbia River).

The dataset containing the predictions of mean warmweather minimum daily dissolved oxygen concentrations and mean warm-weather maximum daily $\mathrm{pH}$ values for the Pacific drainages also includes 90 percent confidence intervals for those predictions, and this information should help inform water-quality evaluations that use those predictions. Ideally, the accuracy of the dissolved oxygen and $\mathrm{pH}$ linear regression models would have been validated by comparing the predictions against a rich dataset of measured values that were not used in the model calibrations. But this validation was not possible because of the limited amount of continuous dissolved oxygen and $\mathrm{pH}$ data available for the Pacific drainages. While the number of stations where model validation was possible ( 15 for dissolved oxygen and 28 for $\mathrm{pH}$ ) was likely adequate, the amount of data at any one water-quality station was 
limited to 3 years of warm period measurements (and often only included 1 or 2 years). It was possible, therefore, that the mean, detrended dissolved oxygen and $\mathrm{pH}$ values measured at the validation stations were not as representative of long-term mean conditions as the measured values used in the regression equations. Therefore, although the errors associated with both model validations were greater than the errors associated with the calibrations, these results do not necessarily show that the dissolved oxygen and $\mathrm{pH}$ regression models were poor predictors of actual conditions. Rather, the model validations might have been compromised by the availability of the validation data.

Finally, while some general criteria were used to select the prediction networks for the dissolved oxygen and $\mathrm{pH}$ models, it was not possible to identify all the reaches where the predictions were not applicable because the reaches were heavily influenced by upstream conditions that could not be accounted for in the regression explanatory data. These included reaches located downstream of dam outlets with elevated dissolved oxygen concentrations caused by air entrainment in spillway releases, reaches located downstream of highly productive water bodies with very low dissolved oxygen concentrations and high $\mathrm{pH}$, and reaches influenced by wastewater discharges and sediments that have high oxygen demands.

\section{Conclusions}

The two datasets described in this report contain the first complete estimates of nutrient, water use, dissolved oxygen, and $\mathrm{pH}$ conditions for the Pacific drainages of the United States, and the techniques used to develop these datasets provide a framework for integrating watershed data across large regions to assess water-quality impairment. The estimates were possible because of the availability of input data and predictions from recent SPARROW modeling, the results from long-term USGS continuous monitoring, and the predictions from recent stream temperature modeling. The development of the dissolved oxygen and $\mathrm{pH}$ linear regression models showed how these three very different types of regional watershed data can be combined to build a set of tools that was not previously available. The predictions from those models will probably be most useful as a screening tool for identifying potential impairment in the Pacific drainages. Water-quality managers, for example, could select reaches in a watershed where the predicted values were outside of the acceptable range for sensitive fish species (in a similar way to what was done regionally in this paper for summer steelhead). They could then use local knowledge about hydrology, water quality, and land use to perform more detailed evaluations. When that type of information is not available, they could use the estimated nutrient and water-use conditions to inform their decisions on how to monitor water-quality and manage upstream nutrient sources. The example applications presented in this paper also showed how estimates of nutrient, water use, dissolved oxygen, and $\mathrm{pH}$ conditions could be useful to water-quality managers by filling in data gaps about impaired water bodies and adding to the overall understanding of water-quality impairment.

\section{References Cited}

Ator, S.W., 2019, Spatially referenced models of streamflow and nitrogen, phosphorus, and suspended-sediment loads in streams of the Northeastern United States: U.S. Geological Survey Scientific Investigations Report 2019-5118, 57 p.

California Department of Fish and Wildlife, 2020, Anadromous fish distribution-Summer steelhead: California Department of Fish and Wildlife, accessed March 2, 2020, at https://www.calfish.org/ProgramsData/Species/A nadromousFishDistribution.aspx.

California Water Resources Control Board, 2017, Final California 2012 integrated report (303(d) List/305(b) Report): California Water Resources Control Board, Supporting information, accessed July 3, 2017, at h ttps://www.waterboards.ca.gov/water_issues/programs/ tmdl/2012state_ir_reports/table_of_contents.shtml.

Center for International Earth Science Information Network, 2019, U.S. EPA National Priorities List Sites with CIESIN Modifications, v2 (2014): New York, New York, Columbia University, Earth Institute, Center for International Earth Science Information Network, accessed December 1, 2019, at https://sedac.ciesin.columbia.edu/data/set/superfund-epanational-priorities-list-ciesin-mod-v2.

Chapra, S.C., Pelletier, G.J., and Tao, H., 2012, QUAL2KA modeling framework for simulating river and stream water quality (version 2.12) - Documentation and users manual: Medford, Massachusetts, Tufts University, Civil and Environmental Engineering Dept.

Cole, T.M., and Wells, S.A., 2006, CE-QUAL-W2-A two-dimensional, laterally averaged, hydrodynamic and water quality model (version 3.5): Vicksburg, U.S. Army Engineering and Research Development Center, Instruction Report EL-06-1, accessed July 3, 2017, at https://pdxscho lar.library.pdx.edu/cengin_fac/130/.

Homer, C.G., Dewitz, J.A., Yang, L., Jin, S., Danielson, P., Xian, G., Coulston, J., Herold, N.D., Wickham, J.D., and Megown, K., 2015, Completion of the 2011 National Land Cover Database for the conterminous United StatesRepresenting a decade of land cover change information: Photogrammetric Engineering and Remote Sensing, v. 81, no. 5 , p. 345-354. 
Hoos, A.B., and Roland, V.L., II, 2019, Spatially referenced models of streamflow and nitrogen, phosphorus, and suspended-sediment loads in the Southeastern United States: U.S. Geological Survey Scientific Investigations Report 2019-5135, 91 p. [Also available at https://doi.org/ 10.3133/sir20195135.]

Horizon Systems, 2013, NHDPlusV2Data: Horizon Systems database, accessed March 18, 2013, at http://www.horizonsystems.com/nhdplus/.

Idaho Department of Environmental Quality, 2017, Idaho's 2012 integrated report: Idaho Department of Environmental Quality, accessed July 3, 2017, at https://www.deq. idaho.gov/water-quality/surface-water/monitoringassessment/integrated-report.aspx.

Isaak, D., Wenger, S., Peterson, E., Ver Hoef, J., Nagel, D., Luce, C., Hostetler, S., Dunham, J., Roper, B., Wollrab, S., Chandler, G., Horan, D., and Parkes-Payne, S., 2017, The NorWeST summer stream temperature model and scenarios for the western U.S.-A crowd-sourced database and new geospatial tools foster a user community and predict broad climate warming of rivers and streams: Water Resources Research, v. 53, no. 11, p. 9181-9205.

LaCroix, Trea, 2015, A nutrient mass balance of Fernan Lake, Idaho, and directions for future research: Moscow, Idaho, University of Idaho, M.S. thesis, 224 p., 42 figs.

Montana Department of Environmental Quality, 2017, 2012 integrated report: Montana Department of Environmental Quality, accessed July 3, 2017, at https://deq.mt.gov/Water/ WQPB/cwaic/reports.

National Renewable Energy Laboratory, 2019, Solar resource data, tools, and maps: National Renewable Energy Laboratory, accessed September 3, 2019, at https://www .nrel.gov/gis/solar.html.

Oregon Department of Environmental Quality, 2017, Water quality assessment — Oregon's 2012 integrated report assessment database and 303(d) list: Oregon Department of Environmental Quality, accessed July 3, 2017, at https:// www.deq.state.or.us/wq/assessment/rpt2012/search.asp.

Pacific States Marine Fisheries Commission, 2020, StreamNet maps and GIS data- Steelhead, summer run: Pacific States Marine Fisheries Commission, accessed March 2, 2020, at https://www.streamnet.org/data/interactive-maps-andgis-data/.

Robertson, D.M., and Saad, D.A., 2019, Spatially referenced models of streamflow and nitrogen, phosphorus, and suspended-sediment loads in streams of the Midwestern United States: U.S. Geological Survey Scientific Investigations Report 2019-5114, 74 p. plus 5 appendixes, https://doi.org/10.3133/sir20195114.
Saad, D.A., Schwarz, G.E., Argue, D.M., Anning, D.W., Ator, S.W., Hoos, A.B., Preston, S.D., Robertson, D.M., and Wise, D.R., 2019, Estimates of long-term mean daily streamflow and annual nutrient and suspended-sediment loads considered for use in regional SPARROW models of the conterminous United States, 2012 base year: U.S. Geological Survey Scientific Investigations Report 2019-5069. [Also available at https://doi.org/10.3133/ sir20195069.]

Schwarz, G.E., Hoos, A.B., Alexander, R.B., and Smith, R.A., 2006, The SPARROW surface water-quality model-Theory, applications and user documentation: U.S. Geological Survey Techniques and Methods, book 6, chap. B3, 248 p. [Also available on CD-ROM and at https://pubs .usgs.gov/tm/2006/tm6b3/.]

Sheibley, R.W., Foreman, J.R., Marshall, C.A., and Welch, W.B., 2014, Water and nutrient budgets for Vancouver Lake, Vancouver, Washington, October 2010-October 2012: U.S. Geological Survey Scientific Investigations Report 2014-5201, 72 p., plus appendixes, https://dx.doi.org/ 10.3133/sir20145201.

Skinner, K.D, and Wise, D.R., 2019, Point-source nutrient loads to streams of the conterminous United States, 2012: U.S. Geological Survey data release. [Also available at https://doi.org/10.5066/P9PYVPFT.]

Tchobanoglous, G., Burton, F.L., and Stensel, H.D., 2003, Wastewater engineering - Treatment and reuse (4th ed.): Boston, McGraw-Hill, 1819 p.

U.S. Environmental Protection Agency (EPA), 2019, National 303(d) listed impaired waters NHDPlus indexed dataset with program attributes: U.S. Environmental Protection Agency, accessed March 1, 2019, at https://www.epa.gov/ waterdata/waters-geospatial-data-downloads\#303d ListedImpairedWaters.

U.S. Environmental Protection Agency (EPA), 2020a, Watershed assessment, tracking \& environmental results system (WATERS): U.S. Environmental Protection Agency, accessed October 23, 2020, at https://www.epa.gov/ waterdata/waters-watershed-assessment-trackingenvironmental-results-system.

U.S. Environmental Protection Agency (EPA), 2020b, Nitrogen and phosphorus pollution data access tool (NPDAT): U.S. Environmental Protection Agency, accessed October 23, 2020, at https://www.epa.gov/waterdata/epanitrogen-and-phosphorus-pollution-data-access-tool\#: :text=The $\% 20$ EPA $\% 20$ Nitrogen $\% 20$ and $\% 20$ Phosphorus, viewer\%20and\%20data\%20download\%20tables.

U.S. Forest Service, 2019, NorWeST regional data base and modeled stream temperatures: U.S. Forest Service, accessed March 1, 2019, at https://www.fs.fed.us/rm/boise/AWAE/ projects/NorWeST.html. 
U.S. Geological Survey, 1999, The quality of our nation's waters-Nutrients and pesticides: U.S. Geological Survey Circular 1225, $82 \mathrm{p}$.

U.S. Geological Survey, 2019a, Water-data site information for the nation: U.S. Geological Survey National Water Information System, accessed March 1, 2019, at https:/ /waterdata.usgs.gov/nwis/si.

U.S. Geological Survey, 2019b, Active mines and mineral plants in the United States: U.S. Geological Survey, accessed December 1, 2019, at https://mrdata.usgs.gov/ mineplant/.

Washington Department of Environmental Conservation, 2017, Washington state water quality assessment: Washington Department of Environmental Conservation, accessed July 3, 2017, at https://fortress.wa.gov/ecy/ approvedwqa/ApprovedSearch.aspx.

Wieczorek, M.E., Jackson, S.E., and Schwarz, G.E., 2019, Select attributes for NHDPlus version 2.1 reach catchments and modified network routed upstream watersheds for the conterminous United States (version 2.0, October 2019): U.S. Geological Survey Data Release, https://doi.org/ 10.5066/F7765D7V.

Wise, D.R., Anning, D.W., and Miller, O.L., 2019, Spatially referenced models of streamflow and nitrogen, phosphorus, and suspended-sediment transport in streams of the southwestern United States: U.S. Geological Survey Scientific Investigations Report 2019-5106, 66 p., https://doi.org/ 10.3133/sir20195106.
Wise, D.R., 2019a, Spatially referenced models of streamflow and nitrogen, phosphorus, and suspended-sediment loads in streams of the Pacific region of the United States: U.S. Geological Survey Scientific Investigations Report 2019-5112, 64 p., https://doi.org/10.3133/sir20195112.

Wise, D.R., 2019b, Application of manure nutrients generated by non-cattle livestock to farmland within the Pacific drainages of the United States, 2012: U.S. Geological Survey data relese, https://doi.org/10.5066/P9V1RY3N.

Wise, D.R., 2019c, Population with on-site wastewater treatment within the Pacific drainages of the United States, 2010: U.S. Geological Survey data release, https://doi.org/ 10.5066/P979BBCQ.

Wise, D.R., 2021, Reach-scale estimates of nutrient, water use, dissolved oxygen, and $\mathrm{pH}$ conditions in the Pacific drainages of the United State: U.S. Geological Survey data release, https://doi.org/10.5066/P9B3BQOW.

Wyoming Department of Environmental Quality, 2017, Wyoming water quality assessment and impaired waters list (2012 Integrated 305[b] and 303[d] report): Wyoming Department of Environmental Quality, accessed July 3, 2017, at http://sgirt.webfactional.com/wqd/water-qualityassessment/resources/reports/. 

Publishing support provided by the U.S. Geological Survey

Science Publishing Network, Tacoma Publishing Service Center

For more information concerning the research in this report, contact the Director, Oregon Water Science Center

U.S. Geological Survey

2130 SW 5th Avenue

Portland, Oregon 97201

https://www.usgs.gov/centers/or-water 


\section{$\frac{\mathbb{2}}{3}$}

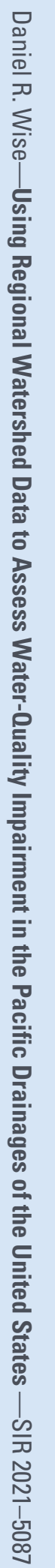

